\title{
Decoding the Neuroprotective Potential of Methyl Gallate-Loaded Starch Nanoparticles against Beta Amyloid-Induced Oxidative Stress-Mediated Apoptosis: An In Vitro Study
}

\author{
Nallasamy Prakashkumar ${ }^{1}$, Bhagavathi Sundaram Sivamaruthi ${ }^{2}$ (D) Chaiyavat Chaiyasut ${ }^{2, *(D)}$ \\ and Natarajan Suganthy ${ }^{1, *}$ \\ 1 Department of Nanoscience and Technology, Alagappa University, Karaikudi 630003, India; \\ prakashkumarnallasamy@gmail.com \\ 2 Innovation Center for Holistic Health, Nutraceuticals and Cosmeceuticals, Faculty of Pharmacy, \\ Chiang Mai University, Chiang Mai 50200, Thailand; sivasgene@gmail.com \\ * Correspondence: chaiyavat@gmail.com (C.C.); suganthyn@alagappauniversity.ac.in (N.S.); \\ Tel.: +66-5394-4340 (C.C.); +91-4565-223375 (N.S.); Fax: +66-5389-4163 (C.C.); +91-4565-225525 (N.S.)
}

Citation: Prakashkumar, N.; Sivamaruthi, B.S.; Chaiyasut, C.; Suganthy, N. Decoding the Neuroprotective Potential of Methyl Gallate-Loaded Starch Nanoparticles against Beta Amyloid-Induced Oxidative Stress-Mediated Apoptosis An In Vitro Study. Pharmaceutics 2021, 13, 299. https://doi.org/10.3390/ pharmaceutics13030299

Academic Editor: Ivana Cacciatore

Received: 21 January 2021

Accepted: 19 February 2021

Published: 25 February 2021

Publisher's Note: MDPI stays neutra with regard to jurisdictional claims in published maps and institutional affiliations.

Copyright: () 2021 by the authors. Licensee MDPI, Basel, Switzerland. This article is an open access article distributed under the terms and conditions of the Creative Commons Attribution (CC BY) license (https:// creativecommons.org/licenses/by/ $4.0 /)$.

\begin{abstract}
Alzheimer's disease (AD) is a multifaceted neuronal disorder and a challenge to medical practitioners, as the blood-brain barrier (BBB) acts as a major obstacle for drug delivery to the brain. Development of a nanomaterial-based drug delivery system (DDS) paved a way to penetrate the BBB. Starch, a ubiquitous natural biopolymer, has received much attention as a DDS due to its biocompatibility, biodegradability and eco-friendly nature. The present study focuses on encapsulating methyl gallate (MG) within starch nanoparticles (starch-encapsulated MG (SEMG)) and assesses its neuroprotective potential against $\beta$-amyloid $(A \beta)$-induced toxicity, the key factor for AD pathogenesis in Neuro2A cells. SEMG showed potent acetylcholinesterase inhibitory, antioxidant activity and anti-amyloidogenic activity by attenuating the fibrillation of $A \beta$ and destabilizing the preformed mature fibrils. Furthermore, SEMG also attenuated the cytotoxic effect induced by A $\beta$ in Neuro2A cells ( $50 \%$ inhibitory concentration $18.25 \pm 0.025 \mu \mathrm{g} / \mathrm{mL}$ ) by mitigating reactive oxygen species (ROS)-mediated macromolecular damage, restoring mitochondrial membrane potential and attenuating apoptosis. Characterization of SEMG revealed amorphous rock-shaped structure with average particle size of $264.6 \mathrm{~nm}$, exhibiting $83 \%$ loading efficiency and sustained release of drug, with $73 \%$ release within $24 \mathrm{~h}$ at physiological $\mathrm{pH}$. Overall, the outcome of the present study signifies starch as a promising nanocarrier for the delivery of drugs for the treatment of AD.
\end{abstract}

Keywords: Alzheimer's disease; starch-encapsulated methyl gallate (SEMG); Neuro2A cells; $\beta$ amyloid peptide; oxidative stress; apoptosis

\section{Introduction}

Starch is an inexpensive renewable polysaccharide ubiquitously found in nature with wide application in industries. Multiple evidences revealed the use of this biopolymer as an encapsulating agent to preserve compounds such as vitamins, lipids, drugs, microorganisms and flavoring agents, polyphenols and herbicides from adverse conditions such as light, temperature and $\mathrm{pH}$, etc. [1]. Mesoporous microstructure of starch, diverse functionalization retaining its physicochemical characteristics and stimuli-based release of drugs reveals starch as a suitable encapsulating agent for delivery of drugs. Starch from natural sources such as potato, maize, corn and cassava, and nonconventional source like amaranth, taro and tapioca, were widely used for encapsulation processes [2,3]. Owing to its biocompatibility, microporosity and biodegradability, starch has been chosen for nanoencapsulation in the present study. 
Alzheimer's disease (AD) is a devastating brain-related degenerative disorder affecting mostly the elderly population above 65 years, and it is considered as one of the greatest medical challenges of the 21st century. The increase in the aging population globally increases the incidence of $\mathrm{AD}$, and currently, around 46.8 million people are affected by dementia, which is supposed to double by 2030 and quadruple by 2050 if no effective therapy intervenes [4]. Clinical symptoms include difficulty in remembering conversation and depression in early days, followed by memory impairment, difficulty in communication, poor judgment, behavioral changes, confusion and disorientation, leading to loss of activities of daily life in later stages, and ultimately leading to death [5]. Cardinal pathological hallmarks are deposition of $\beta$-amyloid $(\mathrm{A} \beta)$ plaques in the synaptic region and neurofibrillary tangles composed of hyperphosphorylated tau in the axonal region, which induces oxidative stress and inflammation-mediated degeneration of neurons primarily in the hippocampal region linked to learning and memory. Degeneration of neurons leads to imbalance in neurotransmitters like acetylcholine, dopamine and serotonin, affecting synaptic neurotransmission and leading to cognitive deficiencies [6]. Despite several researches, pathogenesis and effective treatment for AD have not yet been elucidated. FDA (Food and Drug Administration, United States)-approved drugs such as AChE (Acetylcholinesterase) inhibitors like donepezil, rivastigmine, galanthamine and N-methyl-d-aspartate (NMDA) receptor antagonist memantine have been used for the treatment of mild to moderate $\mathrm{AD}$, however these drugs possess severe side effects [7]. Elucidation of the molecular mechanism of $\mathrm{AD}$ illustrated that $\mathrm{AD}$ is a multifactorial disorder, involving intertwined complex biochemical pathways, so hitting a single target will not be efficient for AD. Although several synthetic drugs were obtained by incorporating one or more pharmacophores within one scaffold, naturally occurring compounds with multipotent activity received much attention. Among the risk factors, aggregation of $A \beta$ peptide plays a pivotal role in $\mathrm{AD}$ pathogenesis, so the current therapeutic strategy also focused on either blocking the amyloid aggregation and/or destroying the already formed aggregates. In silico, in vitro and in vivo studies revealed that several phenolic compounds such as curcumin, dopamine, derivatives of catechin, quercetin and rosmarinic acid showed multitargeted ability for $\mathrm{AD}$ therapeutics [8]. A recent report revealed that physical exercise together with intake of a diet rich in antioxidants, such as the Mediterranean diet, like olive oil, wine, fruits and vegetables rich in polyphenolic content and vitamins $A, C$ and $E$, lowers the risk of $A D$ by attenuating oxidative stress and inflammatory pathways involved in AD pathogenesis $[9,10]$. Another major limitation of AD therapy is the blood-brain barrier (BBB) and drug efflux by P- glycoprotein, which restricts the entry of drugs to the central nervous system (CNS). Nanotechnology-based approaches addressed this problem by adhering or entrapping/encapsulating AD drugs within nanocarriers, thereby promoting sustained release of entrapped drugs [11]. The proposed drug methyl gallate (MG) is a strong phenolic antioxidant widely found in Terminalia myriocarpa, Terminalia chebula, Terminalia arjuna Bergenia ciliata (hairy Bergenia) Geranium niveum and Paeonia anomala [12]. Methyl gallate has been reported for its wide pharmacological activities, such as antiplatelet action, antioxidant property, antiapoptotic, anticancer, antidiabetic and anti-inflammatory activities under in vitro and in vivo conditions $[13,14]$. Although methyl gallate has been reported for its biocompatible nature and neuroprotective effect via antioxidant, anticholinesterase and anti-aggregation properties [15], poor solubility, stability and inability to cross the BBB have turned into major obstacles in the usage of the drug for AD therapy. Hence, the present study focused on nano-encapsulating methyl gallate within a starch matrix to enhance its solubility, bioavailability and BBB permeability as a suitable candidate for AD therapy.

\section{Materials and Methods}

\subsection{Reagents Required}

Maize starch $\left(\mathrm{C}_{6} \mathrm{H}_{10} \mathrm{O}_{5}\right)$ n, potassium ferricyanide, ferric chloride, sodium hydroxide $(\mathrm{NaOH})$, cell culture medium DMEM (Gibco Dulbecco's modified eagle medium), 
FBS (fetal bovine serum) and Trypsin EDTA (Ethylenediaminetetraacetic acid) were obtained from HiMedia laboratories Pvt Ltd., Mumbai India. Methyl gallate, $\mathrm{DCFDH}_{2} \mathrm{DA}$ ( $2^{\prime}, 7^{\prime}$-Dichlorofluorescin Diacetate), JC-1 (5, 5',6, $6^{\prime}$-tetrachloro-1, $1^{\prime}, 3,3^{\prime}$-tetraethylbenzimidazolylcarbocyanine iodide) and DPPH (2, 2-Diphenyl-1-Picrylhydrazyl) were obtained from Sigma Aldrich Pvt Ltd., MumbaiIndia.

\subsection{Loading of Methyl Gallate onto Starch Nanoparticles}

Methyl gallate was loaded into starch nanoparticles by the graft copolymerization method, in which MG was encapsulated within gelatinized starch [16]. About $5 \mathrm{~g}$ of maize starch was boiled in $0.4 \mathrm{M} \mathrm{NaOH}$ solution at $80^{\circ} \mathrm{C}$ for gelatinization, followed by addition of $0.3 \% \mathrm{MG}$ and acetone dropwise under constant stirring for $10 \mathrm{~h}$ at $60{ }^{\circ} \mathrm{C}$. Reaction mixture was frequently extracted with acetone to remove the free MG. Starch-encapsulated MG (SEMG) was separated by centrifugation and dried at room temperature. Dry sample was ground to fine powder, followed by drying in a hot air oven at $80^{\circ} \mathrm{C}$ for $12 \mathrm{~h}$, and samples were stored in an airtight container at room temperature.

\subsubsection{Loading Efficiency of MG}

Methyl gallate-loaded starch nanoparticles were assessed by quantifying the concentration of MG in supernatant at $270 \mathrm{~nm}$ using a UV-Visible spectrophotometer. The concentration of MG was calculated by a calibration graph using different concentrations of MG $(10-50 \mu \mathrm{g} / \mathrm{mL})$. Experiments were carried out in triplicates and the loading efficiency of MG (LE) was calculated as per the formula:

$$
\text { Loading efficiency }=\frac{[\mathrm{MG}]_{\mathrm{T}}-[\mathrm{MG}]_{\mathrm{S}}}{[\mathrm{MG}]_{\mathrm{T}}} \times 100
$$

$[\mathrm{MG}]_{\mathrm{T}}$ - total amount of methyl gallate used for encapsulation, and [MG]s-methyl gallate in the supernatant.

$$
\text { Yield Percentage }=\frac{\text { Total wt of Nanoparticles }}{\text { Total amount of MG }+ \text { Amount of starch used }} \times 100
$$

\subsubsection{Methyl Gallate Release Kinetics}

Release kinetics of MG were assessed under in vitro condition based on the methodology of Winarti et al. [17]. Approximately $50 \mathrm{mg}$ of MG was dissolved in $15 \mathrm{~mL}$ of phosphate buffered saline, $\mathrm{pH} 7.4$, and subjected to constant stirring at $37^{\circ} \mathrm{C}$. At specific ntervals $(4 \mathrm{~h}$ intervals for $24 \mathrm{~h}$ ), the supernatant was collected and replaced with the same volume of fresh PBS (Phosphate buffered saline) solution. The amount of MG released in the supernatant was quantified by a UV-Visible spectrophotometer at $270 \mathrm{~nm}$ using a calibration graph with various doses of standard MG. Percentage of MG released at specific time intervals was calculated using the equation:

$$
\text { Release of MG }(\%)=\frac{[\text { Methyl gallate }]_{\text {Ref }}}{[\text { Methyl gallate }]_{\text {loaded }}} \times 100
$$

\subsubsection{Swelling Studies}

The swelling nature of MG-loaded starch nanoparticle was evaluated by suspending pre-weighted dried MG-loaded starch nanoparticles in $10 \mathrm{~mL}$ of phosphate-buffered saline (pH 7.4) at $37^{\circ} \mathrm{C}$. Weight of the swollen starch nanoparticle was determined at various time intervals. The swelling ratio was calculated based on the following equation:

$$
\text { Swelling Ratio }=\frac{\text { Weight of wet MG }- \text { Weight of dry MG }}{\text { Weight of dry MG }}
$$




\subsection{Characterization}

Absorption spectrum of SEMG was assessed using a UV-Visible spectrophotometer (UV 2450, Shimadzu, Kanagawa, Japan) by scanning between 200 and $800 \mathrm{~nm}$ with resolution of $1 \mathrm{~nm}$. Crystalline nature of SEMG and MG alone was characterized by X-ray diffraction using the $\mathrm{X}^{\prime}$ Pert $\mathrm{PRO}$ Analytical $\mathrm{X}$-ray diffractometer with $\mathrm{Cu} \mathrm{K} \alpha$ radiation, operating at a voltage of $40 \mathrm{kV}$ and current of $30 \mathrm{~mA}$ (PANalytical, Etten Leur, Netherlands). FTIR (Fouriertransform infrared spectroscopy) spectra of SEMG and MG alone were analyzed using the FTIR-Nicolet Thermo spectrophotometer iS5 (USA) instrument by scanning between 4000 and $400 \mathrm{~cm}^{-1}$ with a resolution of $4 \mathrm{~cm}^{-1}$. Morphology of SEMG was examined using atomic force microscopy (AFM) using NT-MDT (NTEGRA modular Scanning Probe Microscopy. Particle size and charge of fabricated SEMG was evaluated using dynamic light scattering (DLS) and zeta potential (ZP) analyzer (Zetasizer Ver. 6.20, UK).

\subsection{Assessment of Neuroprotective Potential of SEMG}

2.4.1. In Vitro Antioxidant Assay

Free Radical Scavenging Assay

Free radical scavenging activity of SEMG and MG was assessed by the DPPH scavenging assay based on the methodology of Shimada et al. [18]. Different doses of SEMG $(10-50 \mu \mathrm{g} / \mathrm{mL})$ were treated with $0.1 \mathrm{mM}$ DPPH in a 96-well microtiter plate and incubated in the dark at RT (Reaction time) for $1 \mathrm{~h}$ at $37^{\circ} \mathrm{C}$, and the absorbance was measured at $517 \mathrm{~nm}$ using a multilabel reader (Molecular Device Spectramax M3, Softmax Pro V5 5.4.1 software. The percentage inhibition of DPPH radical was calculated.

\section{Assessment of Total Reducing Capacity of SEMG}

Reducing power of SEMG was evaluated based on the methodology of Oyaizu [19]. SEMG in different doses $(10-50 \mu \mathrm{g} / \mathrm{mL}$ ) in $0.2 \mathrm{M}$ of phosphate buffer ( $\mathrm{pH}$ 6.6) was treated with $1 \%$ potassium ferricyanide and incubated for $20 \mathrm{~min}$, followed by treating with $10 \%$ Trichloroacetic acid (TCA). Reaction mixture was centrifuged at $650 \mathrm{rpm}$ for $10 \mathrm{~min}$. Supernatant was mixed with equal volume of water followed by addition of $0.1 \% \mathrm{FeCl}_{3}$, and the absorbance was measured at $700 \mathrm{~nm}$.

\subsubsection{Evaluation of Acetylcholinesterase Inhibitory Activity of SEMG}

Acetylcholinesterase (AChE) inhibitory activity was assessed based on the methodology of Ingkaninan et al. [20], with slight modification. Various doses of SEMG $(10-50 \mu \mathrm{g} / \mathrm{mL})$ were treated with AChE $(10 \mathrm{U} / \mathrm{mL})$ in $0.1 \mathrm{M}$ Tris- $\mathrm{HCl}$ buffer $(\mathrm{pH} 8.0)$, for about $2 \mathrm{~h}$ at RT, followed by the addition of $3 \mathrm{mM}$ DTNB ((5,5'-dithiobis-(2-nitrobenzoic acid)). Enzyme reaction was initiated by the addition of ATCI $(15 \mathrm{mM})$ and the absorbance was read at $405 \mathrm{~nm}$ every $30 \mathrm{~s}$ for 3 min using a multilabel reader (Molecular Device Spectramax M3, Softmax Pro V5 5.4.1 software). The percentage of inhibition was calculated as the percentage of rate of reaction of test compound in comparison with vehicle control:

$$
\% \text { of inhibition }=\frac{\text { Specific activity of control }- \text { Specific activity of treated }}{\text { Specific activity of control }} \times 100
$$

2.4.3. Assessment of Anti-Aggregation and Disaggregation Potential of SEMG Preparation of A $\beta$ Peptide Monomer

$A \beta$ (25-35), purchased as lyophilized powder, was dissolved in 1,1,1,3,3,3,hexafluoro 2 propanol (HFIP), sonicated for $2 \mathrm{~h}$. Reaction mixture was lyophilized, reconstituted in $1 \mathrm{~mL}$ milli-Q water to a final concentration of $1 \mathrm{mM}$ and stored at $-20^{\circ} \mathrm{C}$ until further use.

\section{A $\beta$ Aggregation Kinetic Study}

Kinetic study on effect of SEMG against $A \beta$ aggregation was evaluated by treating freshly prepared solution of $\mathrm{A} \beta(25-35)$ monomers $(100 \mu \mathrm{M})$ in Tris- $\mathrm{HCl}(\mathrm{pH} 7.4)$ in the presence and absence of various doses of SEMG $(25$ and $50 \mu \mathrm{g} / \mathrm{mL})$ for $96 \mathrm{~h}$ at $37^{\circ} \mathrm{C}$. Every 
$6 \mathrm{~h}$, aliquots of reaction mixture were taken and assessed for aggregation based on the Thioflavin-T (Th-T) assay.

\section{Effect of SEMG on A $\beta$ Aggregation}

Freshly prepared solution of $\mathrm{A} \beta(25-35)$ monomers in Tris- $\mathrm{HCl}$ ( $\mathrm{pH} 7.4)$ to final concentration of $100 \mu \mathrm{M}$ was incubated at $37^{\circ} \mathrm{C}$ for $20 \mathrm{~h}$ to form oligomers. SEMG $(50 \mu \mathrm{g} / \mathrm{mL})$ was incubated with oligomeric mixture for $48 \mathrm{~h}$ and aliquots were drawn from the incubation mixture at 20 and $48 \mathrm{~h}$ respectively, for spectrofluorimetric and confocal microscopy analysis by Th-T assay based on the methodology of Khurana et al. [21]. Aliquots of reaction mixture was treated with $5 \mu \mathrm{M}$ Th-T in Glycine- $\mathrm{NaOH}$ buffer, $\mathrm{pH}$ 8.5, and the fluorescence intensity was measured at excitation/emission wavelength $450 / 485 \mathrm{~nm}$ in a multi-mode plate reader (Molecular Device Spectramax M3). For CLSM (Confocal Laser Scanning Microscopy) analysis, aliquots of A $\beta$ (25-35) peptide sample were diluted 2 times with $5 \mu \mathrm{M}$ Th-T and transferred onto a slide. Fluorescent signals were then visualized by the confocal laser microscope system (CLSM 710, Carl Zeiss, Germany) and processed by software (Zen 2011). The fluorescence intensity was visualized in each of three random fields of the sample.

Fibril Disaggregation Assay

Mature fibrils were formed by incubating A $\beta$ (25-35) in Tris- $\mathrm{HCl}$ ( $\mathrm{pH} 7.4$ ) for $96 \mathrm{~h}$. Ability of SEMG to destabilize the mature fibrils was assessed by incubating SEMG $(50 \mu \mathrm{g} / \mathrm{mL})$ for 9 days and the aliquots were drawn for spectroscopic and confocal microscopic studies.

2.4.4. Assessment of Neuroprotective Effect of SEMG Against A $\beta$ (25-35)-Induced Toxicity in Neuro2A Cells

Neuro2A cells obtained from the National Center for Cell Sciences (NCCS), Pune, India, were used as an in vitro model system to assess the $\beta$-amyloid $(\mathrm{A} \beta)$-induced toxicity. Cells were cultured in DMEM medium containing $10 \% \mathrm{FBS}$ and $1 \times$ penicillin-streptomycin in a $\mathrm{CO}_{2}$ incubator at $37^{\circ} \mathrm{C}$.

\section{3-(4,5-Dimethylthiazol-2-yl)-2,5-diphenyl-2H-tetrazolium bromide (MTT) Assay}

Pre-seeded Neuro2A cells $\left(2 \times 10^{5}\right.$ cells $\left./ \mathrm{mL}\right)$ were treated with various doses of $\mathrm{A} \beta$ (25-35) $(10-50 \mu \mathrm{M})$ for $24 \mathrm{~h}$ followed by PBS wash and treatment with MTT $(1 \mathrm{mg} / \mathrm{mL})$ for $3 \mathrm{~h}$ at $37^{\circ} \mathrm{C}$. The cells were subjected to PBS wash and the blue-colored formazan crystals were solubilized by DMSO (Dimethyl sulfoxide). Absorbance was measured at $540 \mathrm{~nm}$ using a multi-plate reader. Protective effect of SEMG $(20-100 \mu \mathrm{g} / \mathrm{mL})$ was assessed by pre-treating with SEMG for $2 \mathrm{~h}$ prior to A $\beta(25-35)$ at $20 \mu \mathrm{M}$ concentration and incubated for $24 \mathrm{~h}$, and then subjected to the MTT assay [22].

Measurement of Intracellular ROS Formation

Intracellular reactive oxygen species (ROS) level was evaluated by measuring the change in fluorescence as a result of oxidation of the fluorescent probe DCFH-DA $\left(2^{\prime}, 7^{\prime}\right.$ Dichlorofluorescin Diacetate) [23]. Neuro2A cells were pretreated with SEMG at its 50\% inhibitory concentration $\left(\mathrm{IC}_{50)}(18.25 \pm 0.025 \mu \mathrm{g} / \mathrm{mL})\right.$ for $2 \mathrm{~h}$ followed by $\mathrm{A} \beta(20 \mu \mathrm{M})$ for $24 \mathrm{~h}$. Cells were harvested and treated with DCFH-DA $(10 \mu \mathrm{M})$ for $30 \mathrm{~min}$ at $37^{\circ} \mathrm{C}$ in the dark followed by PBS wash to remove the extracellular DCFH-DA, and examined under a fluorescent microscope (Nikon ECLIPSE, Ti-E, Japan). Quantification of intracellular ROS was carried out by incubating the cells in lysis buffer (10 mM Tris, $20 \mathrm{mM}$ EDTA and $0.25 \%$ Triton X-100) and the intensity of fluorescence was measured using a multi-mode plate reader with the excitation/emission wavelength of $485 / 535 \mathrm{~nm}$, respectively.

Evaluation of Mitochondrial Membrane Potential $(\Delta \Psi \mathrm{m})$

Loss of $\Delta \Psi \mathrm{m}$ in cells treated with SEMG was analyzed using lipophilic cationic dye (JC-1), based on the methodology of Sivandzade et al. [24]. Cell line was treated with SEMG 
for $24 \mathrm{~h}$ followed by treatment with JC- $1(1 \mu \mathrm{g} / \mathrm{mL})$ for $30 \mathrm{~min}$ at $37^{\circ} \mathrm{C}$ in the dark. After the incubation period, the excess dye was removed by PBS wash and the fluorescence intensity was measured at excitation/emission wavelength $(488 / 525 \mathrm{~nm})$ using a multi-mode plate reader. For morphological analysis, the cells were grown in cover slip and subjected to JC-1 staining, followed by visualization using fluorescence microscopy (Nikon ECLIPSE, Ti-E, Japan).

\section{Assessment of Macromolecular Damage}

Lipid peroxidation was assessed according to the method of Ohkawa et al. [25] and the results were expressed as $\mathrm{mM}$ of TBARS (Thiobarbituric acid reactive substance)/mg of protein, with MDA (Malondialdehyde) as standard. Protein carbonyl content was measured according to the method of Levine et al. [26] and the results are expressed as $\mathrm{mM}$ of free carbonyl content/mg of protein.

\section{Morphological Assessment of Apoptosis}

Acridine orange and ethidium bromide $(\mathrm{AO} / \mathrm{EtBr})$ dual-staining technique was used to visualize nuclear changes and apoptotic body formation of the characteristic features of apoptosis [27]. Following A $\beta$ treatment, Neuro2A was washed with PBS and stained with $\mathrm{AO} / \mathrm{EtBr}$ solution $(1: 1, v / v)$ to a final concentration of $10 \mu \mathrm{g} / \mathrm{mL}$ for $10 \mathrm{~min}$. The cells were visualized under a fluorescence microscope (excitation and emission 490/525 nm). Each field of cells was photographed (magnification $\times 400$ ) for calculation of the relative fluorescence intensity. The cells with condensed or fragmented nuclei were counted as apoptotic cells. All experiments were repeated thrice and about 100 stained cells were counted in 10 randomly selected fields.

\subsection{Statistical Analysis}

All the experiments were conducted in triplicate and one-way analysis of variance (ANOVA) (SPSS 17) was used to compare the mean values of each treatment. Significant differences between the means of parameters were determined by using the Duncan's test $(p<0.05)$ comparing between the groups control vs treated. $\mathrm{IC}_{50}$ values were calculated using Probit software (Probit Software LTD, New York, NY, USA).

\section{Results and Discussion}

\subsection{Nanoencapsulation of 7-Methyl Gallate}

Loading of MG into starch nanoparticles was achieved through bonding behavior of sodium alkoxide ion pairs present in the gelatinized starch with the hydroxyl end of MG. The retro gradation kinetics degrades the crystalline nature of the starch by dislocating the units of amylose and amylopectin in starch due to the transfer of moisture content along with acetone during the process of drying. During the process of drying at $80{ }^{\circ} \mathrm{C}$, the nano-encapsulated MG gets grafted as nanoparticles, i.e., SEMG. The observation of drug loading determines that about $87 \%$ of methyl gallate was encapsulated from the total amount of methyl gallate taken for nanoencapsulation. However, the percentage of yield for nano-encapsulated methyl gallate is around $88.3 \%$ from the $2: 10$ ratio of starch and methyl gallate.

\subsubsection{UV-Visible Spectral Analysis}

UV-Visible absorption spectra of MG showed peaks at 214 and $271 \mathrm{~nm}$, in accordance with the report of Zhang et al. [28]. SEMG showed an absorption peak at $274 \mathrm{~nm}$ (Figure 1A), close to the MG spectrum. The slight change in SEMG peak is due to red shift corresponding to the removal of proton from the phenolic group of $\mathrm{MG}$ due to the addition of $\mathrm{NaOH}$ into MG during the process of nanoencapsulation. The bathochromic shift on SEMG is attributed to the fact that phenolic content of methyl gallate and starch nanoparticles were interconnected with hydrogen bonding [29]. 
(A)
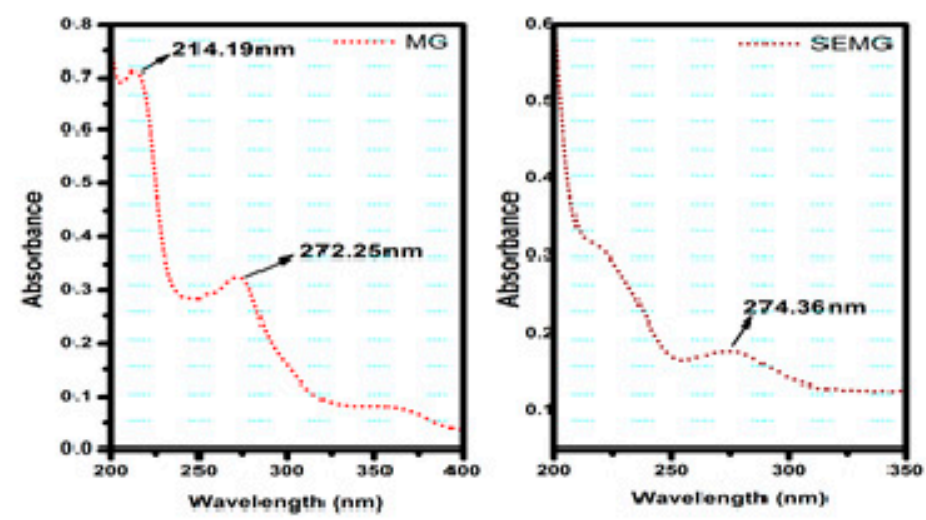

(B)

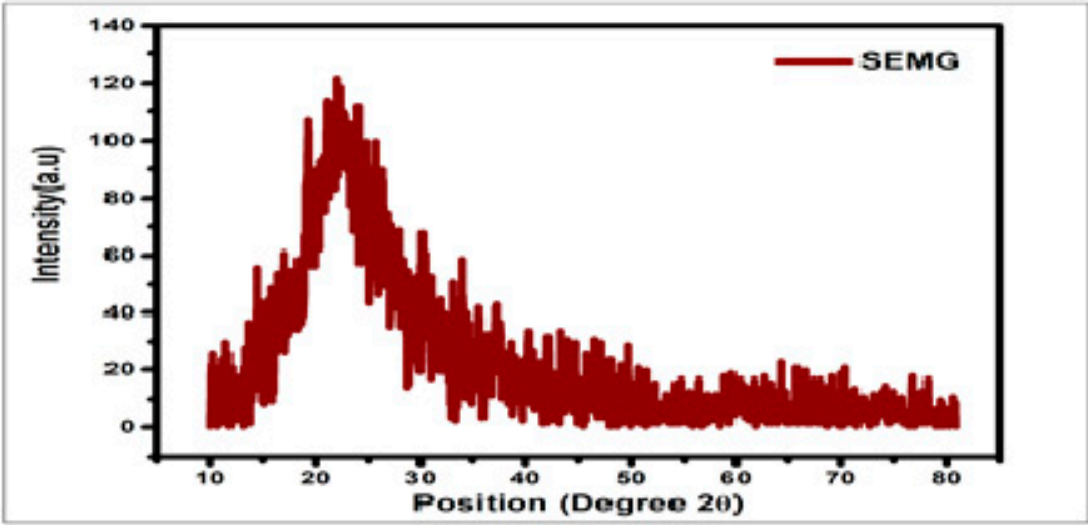

(C)

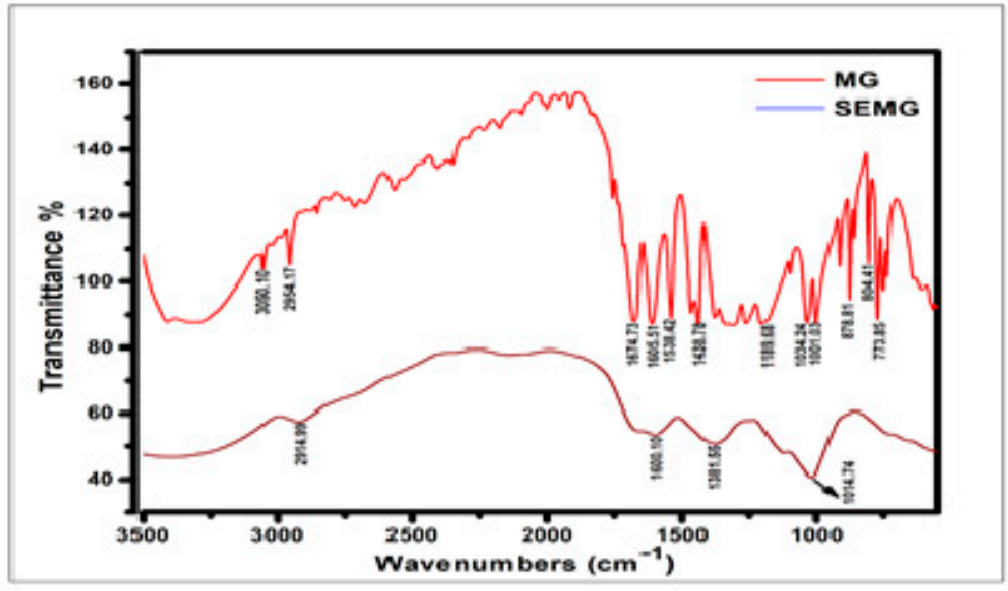

Figure 1. (A) UV-Visible spectrum of Methyl Gallate (MG) and Starch encapsulated methyl gallate (SEMG), (B) Powdered XRD spectrum of SEMG, (C) FTIR spectrum of SEMG (blue) and MG alone (red).

\subsubsection{X-ray Diffraction (XRD) Pattern of SEMG}

According to our previous investigation, nanoencapsulation of organic compounds such as drugs, enzymes or the ayurvedic compounds with starch exhibits amorphous nature [16]. In the present study, the crystalline nature of retrograded starch was altered due to the phase transfer on amylose and amylopectin units as a chain of polymer. Crystalline nature of $\mathrm{MG}$ was denatured due to the displacement of $\mathrm{H}_{2} \mathrm{O}$ with acetone from the gelatinized starch associated with MG during the process of drying [30], resulting in the formation of amorphous SEMG nanoparticles (Figure 1B). 


\subsubsection{FTIR Spectra}

FTIR spectra of MG alone and MG encapsulated with starch nanoparticles (SEMG) were shown in Figure 1C. Spectral variations of FTIR analysis were intensively noticed between MG and SEMG to find out the interaction of MG with starch nanoparticles. The major peaks for MG alone were observed at 3050.10, 2954.17, 1674.73, 1605.51, 1538.42, 1438.78, $1189.68,1034.24,1001.03,878.81,804.41$ and $773.85 \mathrm{~cm}^{-1}$, corresponding to C-H stretch of aromatics, $\mathrm{C}=\mathrm{O}$ stretch of general carbonyl group, $\mathrm{C}-\mathrm{C}$ stretch in aromatic ring, $\mathrm{N}-\mathrm{O}$ asymmetric stretching frequency of nitro compounds, $\mathrm{C}-\mathrm{N}$ stretching frequency of aliphatic amines, $\mathrm{C}-\mathrm{O}$ stretching frequency of esters, $=\mathrm{C}-\mathrm{H}$ bends of alkenes and overtones of $\mathrm{C}-\mathrm{H}$ bends. In case of SEMG, the peak intensities were probably altered in MG at $2914.99 \mathrm{~cm}^{-1}$, from $2954.17 \mathrm{~cm}^{-1}$ of alkanes C-H stretch, and $1601.10 \mathrm{~cm}^{-1}$, from $1605.51 \mathrm{~cm}^{-1}$ of C-C stretch in aromatic ring. The specific frequencies of esters at around $1000 \mathrm{~cm}^{-1}$ were observed in both MG and SEMG, specifying the ester derivative of gallic acid, i.e., methyl gallate [31]. On the other hand, the peak intensity was found at around $1381.55 \mathrm{~cm}^{-1}$ owing to the functional frequency for $\mathrm{C}-\mathrm{H}$ bending of starch nanoparticles [32]. However, the significant spectral variation of FTIR for both MG and SEMG confirms the encapsulation kinetics in-between starch nanoparticles and MG.

\subsubsection{Morphology, Size and Stability of SEMG}

The two-dimensional (2D) micrograph of AFM displays the randomly arranged nanoparticles of SEMG without any kind of agglomeration, and the three-dimensional (3D) topography of AFM shows the possible protrudes of SEMG (Figure 2A). Morphology of SEMG revealed the presence of individual rock-shaped nanoparticles and the shapes of the particles were slightly uneven when compared to one another due to their amorphous nature, as revealed by XRD analysis.

DLS analysis revealed that the average particle size of SEMG was observed to be $264.6 \mathrm{~nm}$ (Figure 2B) based on the detection on Brownian motion of particles in fluids, and it was found to be significantly smaller than the particles of bulk starch, which was reported to be around $1000 \mathrm{~nm}$ and above [33]. Polydispersity index (PDI) value of SEMG is 0.170 , which indicates middle range of particle dispersity due to the encapsulation kinetics between the starch nanoparticles and MG, i.e., graft co-polymerization. Kumari and Yadav [34] reported that cellular uptake of nanoparticles is possible up to a particle size of $500 \mathrm{~nm}$ via endocytosis. Based on this context, the cellular uptake of SEMG is possible as its size is less than $300 \mathrm{~nm}$. Zeta potential analysis of SEMG was observed to be $-25.4 \mathrm{mV}$ (Figure 2C), and this kind of net negative charge nano-carrier facilitates the enhanced cellular uptake with no particle agglomeration through the electrostatic repulsion.

\subsubsection{In Vitro Drug Release Kinetics}

In vitro drug release kinetics of SEMG were assessed in PBS (phosphate-buffered saline) at physiological $\mathrm{pH} 7.4$ for $24 \mathrm{~h}$ under constant stirring. The surface erosion and swelling behavior of nano-carrier (SEMG) upon the PBS system initiates the process of breaking of hydrogen bonds between the starch nanoparticles and MG, which is significantly responsible for the release of MG [35]. Concentration of drug release was assessed by UV-visible spectroscopic analysis of supernatant collected every $4 \mathrm{~h}$. The drug release of MG consecutively increased by $\sim 12 \% \pm 2 \%$ up to $16 \mathrm{~h}$ and the constant cumulative release was observed to be $73 \%$ during the period of 20 to $24 \mathrm{~h}$, revealing the fact that maximum release of methyl gallate from the methyl gallate loaded starch nanocarrier $(83 \%)$ was observed within $24 \mathrm{~h}$ (Figure 2D). Moreover, the swelling ratio was observed to be $3.9 \%$ in $24 \mathrm{~h}$, when the drug release was observed to be $73 \%$. This result illustrates SEMG as a suitable nano-carrier for the sustained release of MG. 
(A)

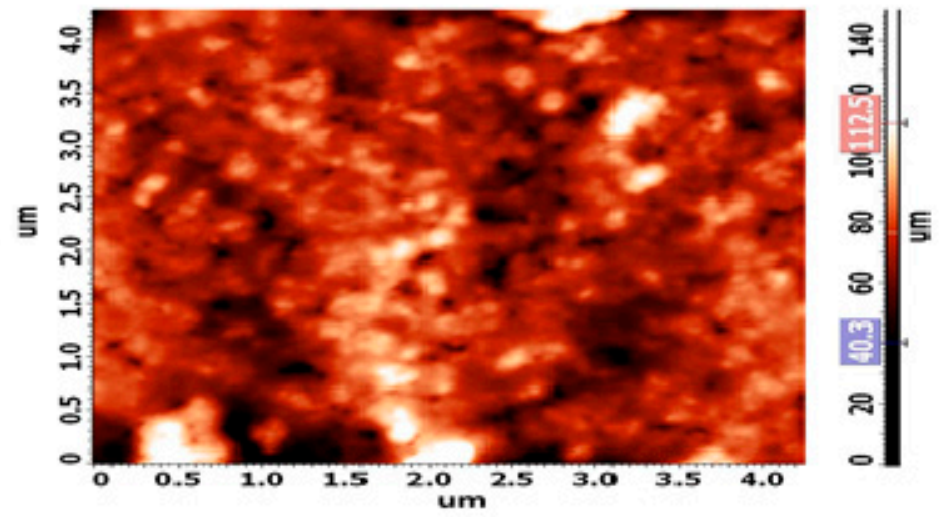

(B)

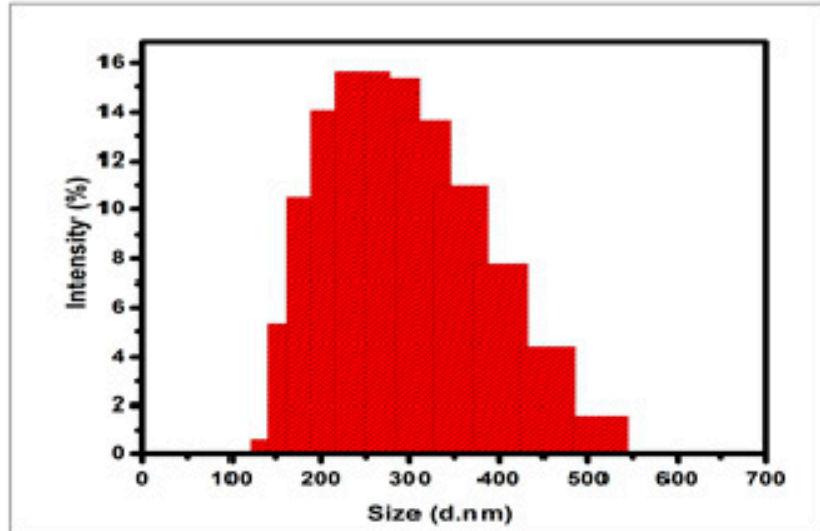

(C)

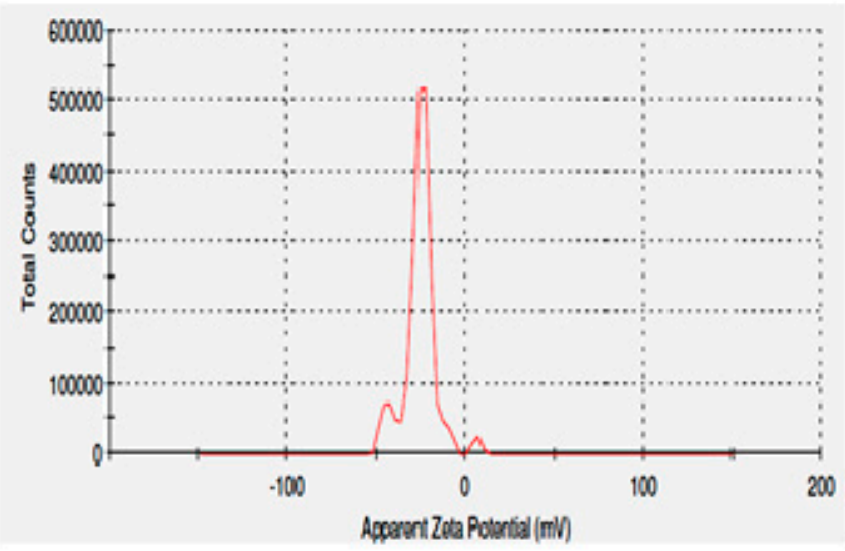

(D)

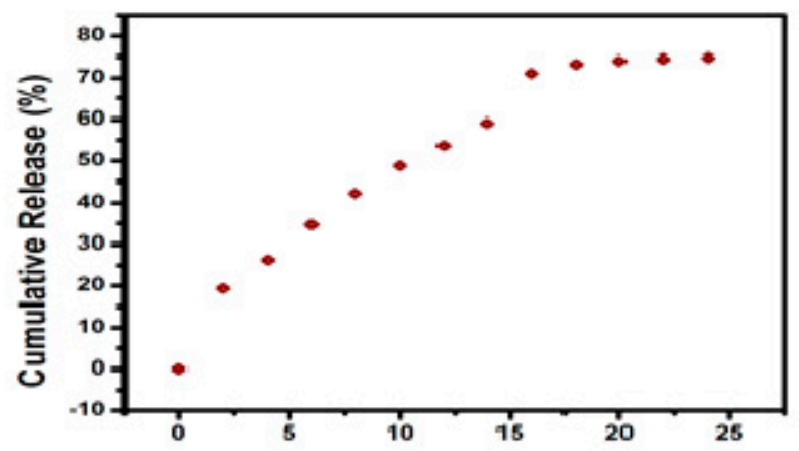

Figure 2. (A) Atomic Force Micrographs (AFM) of SEMG (2D and 3D image), (B) particle size distribution of the SEMG, (C) zeta potential measurement of SEMG, (D) In vitro release kinetics of Methyl Gallate (MG) from SEMG. 


\subsubsection{Neuroprotective Potential of SEMG}

Alzheimer's disease is the acquired dementia characterized by the progressive degeneration of neurons, leading to cognitive deficits and behavioral symptoms, which intensify with time, creating a major health challenge for the medical practitioners [36]. Current research on biomarkers of $\mathrm{AD}$ revealed that deposition of $\mathrm{A} \beta$ is the foremost and key pathogenic event in AD pathogenesis, which in turn promotes NFT formation, activating oxidative stress and inflammatory pathways, and ultimately leading to neuronal death. Failure in current therapeutic strategies for AD therapy is due to the blood-brain barrier (BBB), which blocks the entry of drugs into the central nervous system (CNS) [37]. Contemporary research revealed that fabricating nanomaterials within the nano platform enhances the efficiency of drugs through targeted drug delivery and sustained drug release, thereby minimizing side effects [38]. Although methyl gallate has been reported for its antioxidant and neuroprotective effects under in vitro conditions, poor solubility and gastrointestinal disturbances at higher doses limits its clinical efficiency. Hence, the present work focused on nano-encapsulating methyl gallate within starch biopolymer and evaluating its neuroprotective potential against $\mathrm{A} \beta$-induced toxicity under in vitro conditions.

\section{In Vitro Acetyl Cholinesterase Inhibitory and Antioxidant Activity}

In $\mathrm{AD}$, the major causative agent for cognitive decline is degeneration of cholinergic neurons associated with loss of neurotransmission due to reduction in the level of neurotransmitter acetyl choline (ACh) [39]. As current therapeutic strategies focus on the use of acetylcholinesterase (AChE) inhibitors which restore the acetylcholine level, enhancing the cognitive function, the present study was carried out to assess the AChE inhibitory activity of SEMG. Results revealed that SEMG showed dose-dependent AChE inhibitory activity, with the highest inhibition rate of $83.75 \pm 2.36 \mu \mathrm{g} / \mathrm{mL}$ at $50 \mu \mathrm{g} / \mathrm{mL}$ (Figure 3C), similar to the inhibitory effect of the same dose of MG and positive control ( $76 \% \pm 1.40 \%$ and $80.05 \% \pm 0.023 \%$, respectively). IC 50 value of SEMG and MG was observed to be $15.25 \pm 0.024$ and $35.25 \pm 0.04 \mu \mathrm{g} / \mathrm{mL}$, respectively. Results illustrate that starch encapsulation restored the AChE activity of MG, indicating it as a suitable drug delivery system.

Mounting evidences revealed that oxidative stress observed in early stages of $\mathrm{AD}$ plays a vital role in triggering complex signaling pathways, leading to pathogenesis of $\mathrm{AD}$ and lesion formation [40]. Antioxidant therapies were recently observed to be successful in preclinical trials for the treatment of $\mathrm{AD}$. In the present study, the antioxidant capacity of SEMG was assessed and the results were shown in Figure 3A,B. Results of the present study illustrated that nano-encapsulated drugs showed potent free radical scavenging activity in a dosedependent manner $(10-50 \mu \mathrm{g} / \mathrm{mL})$, with highest DPPH radical scavenging activity of $82.28 \%$ $\pm 2.17 \%$ at $50 \mu \mathrm{g} / \mathrm{mL}$, similar to the same dose of standard BHT (Butylated hydroxytoluene) $(96 \% \pm 0.001 \%) . \mathrm{IC}_{50}$ values of nano-encapsulated drug, drug alone and standard BHT were observed to be $9.83 \pm 0.05,26.05 \pm 0.025$ and $12.04 \pm 0.04 \mu \mathrm{g} / \mathrm{mL}$, respectively.

Reducing capacity of compound depends on the electron-donating ability, which was assessed based on the ability to convert ferricyanide complex to ferrous form, and the change in color was measured at $700 \mathrm{~nm}$. Figure 3A illustrated that SEMG showed increased absorbance $(2.98 \pm 0.008$ a.u. (Arbitrary unit)) similar to positive control ascorbic acid (2.40 \pm 0.05 a.u.) in a concentration-dependent manner, and higher than drug alone (1.24 \pm 0.013 a.u.). Enhanced reducing ability of SEMG might be due to the synergistic effect of the antioxidant ability of starch nanoparticles and methyl gallate [15]. Results of the present study illustrate that nanoencapsulation of 7-MG retains the antioxidant capacity of the drug, revealing it as a suitable DDS. 
(A)

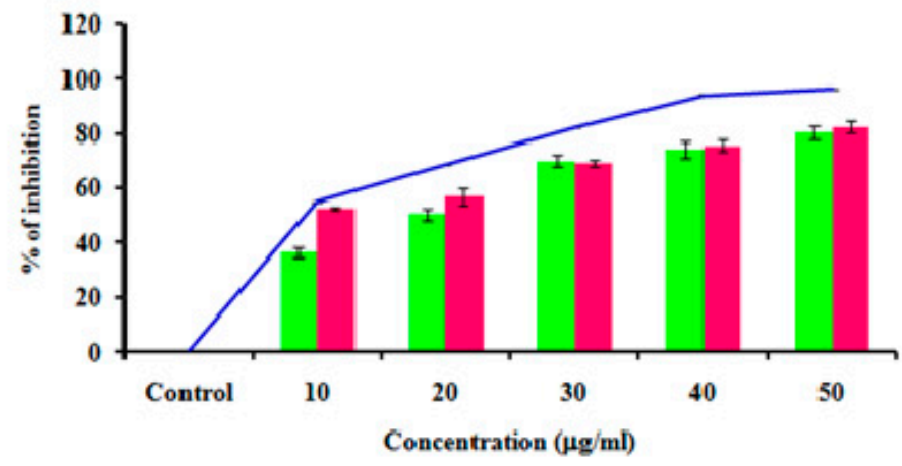

7MG $=$ SEMG - BHT

(B)

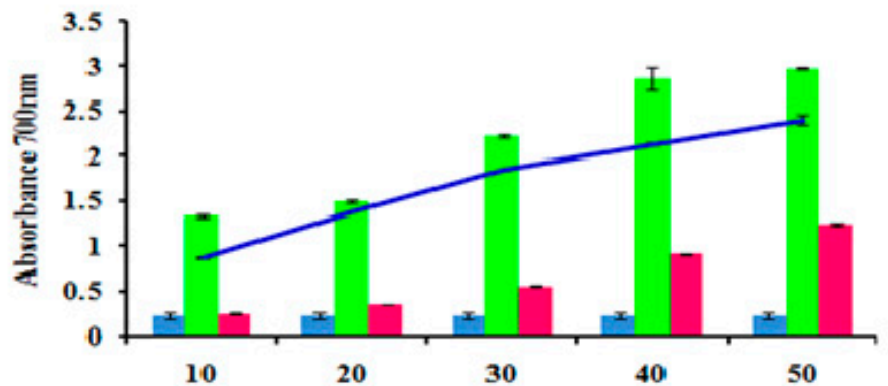

Control SEMG $=7 \mathrm{MG}=$ Ascorbic acid

(C)

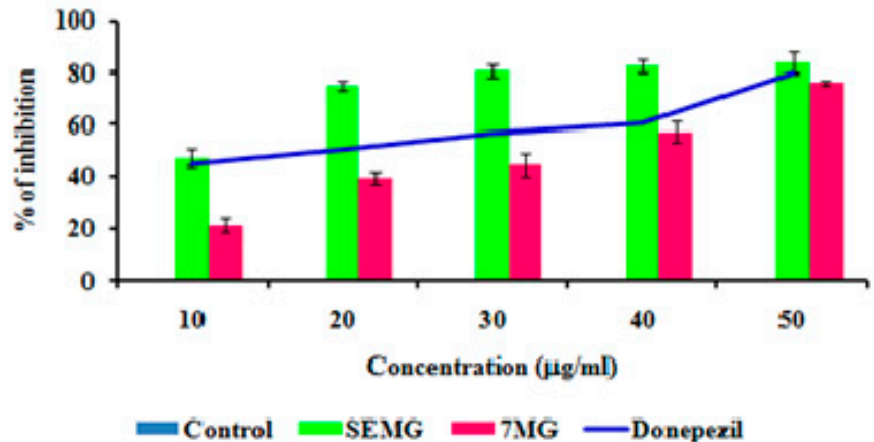

Figure 3. (A) Free radical scavenging activity of SEMG compared to standard Butylated hydroxytoluene, (B) Reducing power of SEMG in comparison with positive control ascorbic acid, (C) Acetylcholinesterase inhibitory activity of SEMG compared to standard drug donepezil. Results are expressed as Mean \pm SD of triplicate assays.

\section{Anti-Aggregation and Disaggregation Ability of SEMG}

Aberrant misfolding and aggregation of $A \beta$ peptide into fibrils is the critical event which aggravates the pathogenesis of $\mathrm{AD}$, hence researchers focused on investigating compounds that avert aggregation of $A \beta$ peptide. Several phyto-compounds rich in polyphenolic content have been reported to attenuate the aggregation of $A \beta$ peptide or destabilize the preformed fibrils. In addition, the drug MG has been reported for its potent anti-aggregation and $A \beta$ mature fibril destabilizing ability [15]. The present study was carried out to assess whether MG retains the anti-aggregation ability after encapsulation within the starch nanoparticles. Thioflavin-T, a classical benzothiazole dye on intercalation between $A \beta$ fibrils, exhibits enhanced fluorescent intensity, and this dye has been widely used as a probe for the detection of $A \beta$ fibrillization process. Results of kinetics studies of $A \beta$ fibrillation were shown in Figure $4 \mathrm{~A}$, which exhibited a sigmoidal curve revealing a 
time-dependent increase in fluorescence intensity, illustrating the polymerization of $A \beta$ (25-35) monomers to fibrils at $48 \mathrm{~h}$ and mature plaques ( $96 \mathrm{~h}$ ) when compared to Th-T blank alone.

(A)

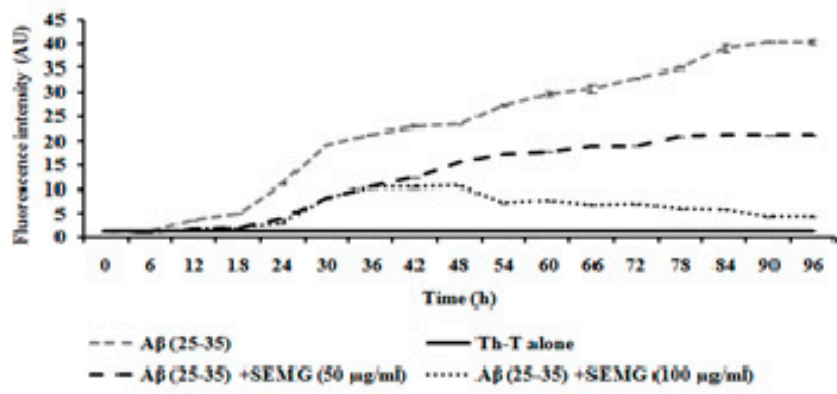

(B)

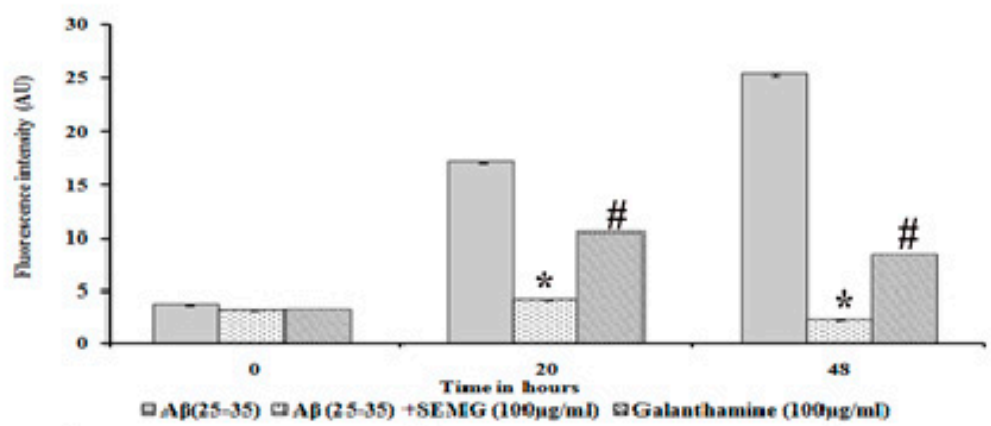

(C)
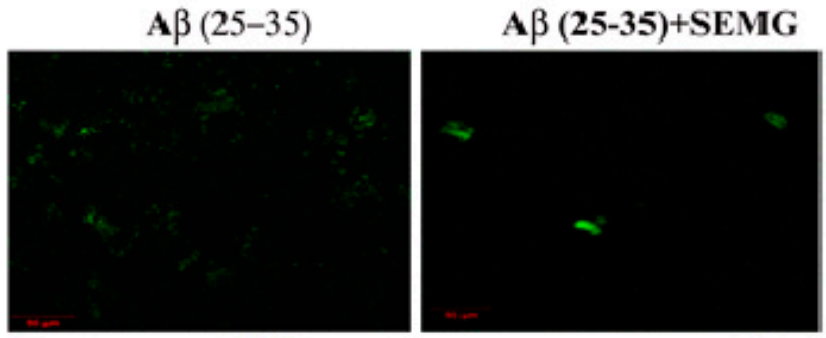

A $\beta(25-35)+$ Gal

$20 \mathrm{~h}$
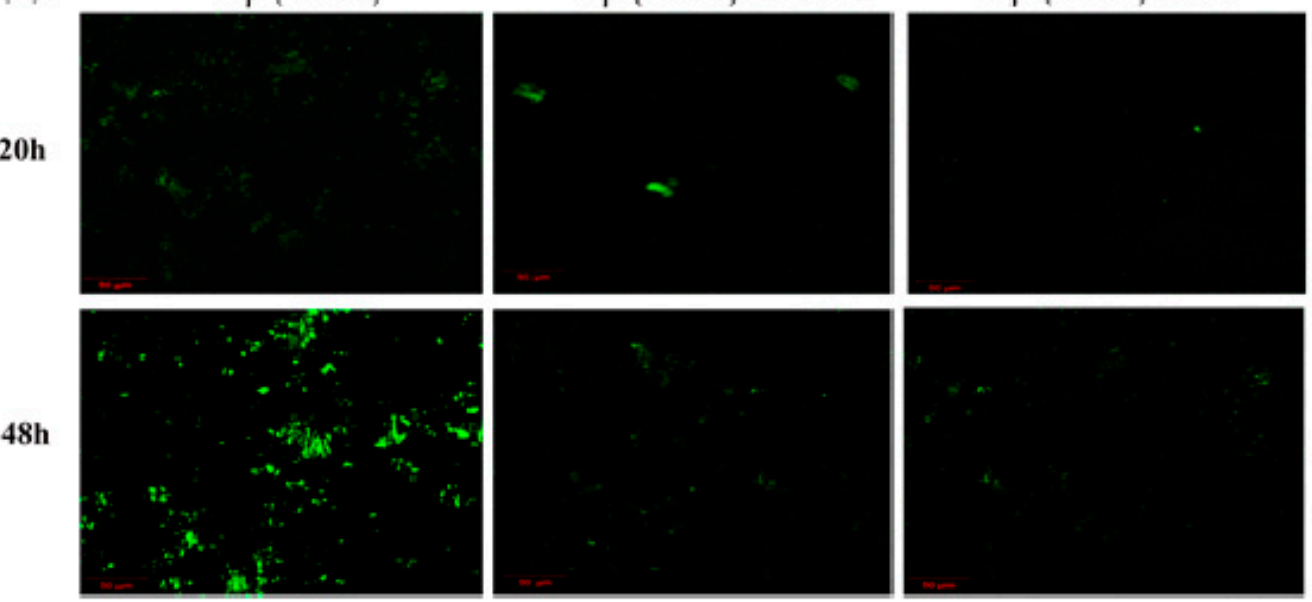

Figure 4. Anti-aggregation potential of SEMG against A $\beta$ (25-35) preformed oligomers. (A) Sigmoidal curve representing aggregation kinetics of $\mathrm{A} \beta$ (25-35) from monomers to mature fibrils in the presence and absence of SEMG. (B) Th-T fluorescence assay. (C) Confocal microscopic analysis with $20 \times$ magnification ${ }^{*}, \# p<0.05$ represents statistically significant difference in comparison with treated groups with control and positive control group.

The SEMG (50 and $100 \mu \mathrm{g} / \mathrm{mL}$ )-treated group showed a decrease in fluorescence intensity in the elongation phase, illustrating minimal $A \beta$ fibrillation. In addition, SEMG $(100 \mu \mathrm{g} / \mathrm{mL})$-treated groups showed increased lag phase of aggregation, revealing the fact that SEMG might have stabilized the native unfolded peptide, thereby intervening the aggregation of $A \beta$ peptide. In a Phase I study, $A \beta$ (25-35) peptide showed a fiveand eight-fold increase in fluorescent intensity at 20 and $48 \mathrm{~h}$, revealing the formation of protofibrils and oligomers from $A \beta$ monomer. Upon co-treatment with SEMG, the fluorescent intensity reduced by four-fold $(4.15 \pm 0.019$ a.u. $)$ and ten-fold $(2.25 \pm 0.03$ a.u. $)$ after 20 and $48 \mathrm{~h}$, illustrating the fact that SEMG efficiently attenuated the formation of oligomers from $A \beta$ monomers (Figure $4 B$ ). Results were further substantiated by CLSM 
images, which showed enhanced green fluorescent intensity in the vehicle control, while SEMG- and galanthamine-treated groups showed a reduction in fluorescent intensity (Figure $4 C$ ), revealing the ability of SEMG to inhibit aggregation of $A \beta$ fibrils.

In a Phase II study, an increase in fluorescence intensity was observed in $A \beta(25-35)$ treated groups from $96 \mathrm{~h}(30.89 \pm 0.63$ a.u.) to 9 days (50.22 \pm 0.24 a.u.), revealing the formation of mature plaques from oligomers. Treatment with SEMG and galanthamine showed a remarkable decline in fluorescent intensity by four- and six-fold when compared to vehicle control, indicating the disaggregation of mature fibrils and attenuation of selfassembly of mature fibrils to amyloid plaques by SEMG (Figure 5A). Furthermore, results of confocal microscopic studies showed enhanced green fluorescence intensity in the A $\beta$ treated group with a decline in fluorescent intensity in SEMG-treated groups (Figure 5B). The outcome of the study reveals that SEMG restored the anti-aggregation and fibril destabilizing ability of 7-MG, indicating that SEMG could be used as an anti-amyloidogenic agent for $\mathrm{AD}$ treatment.

(A)
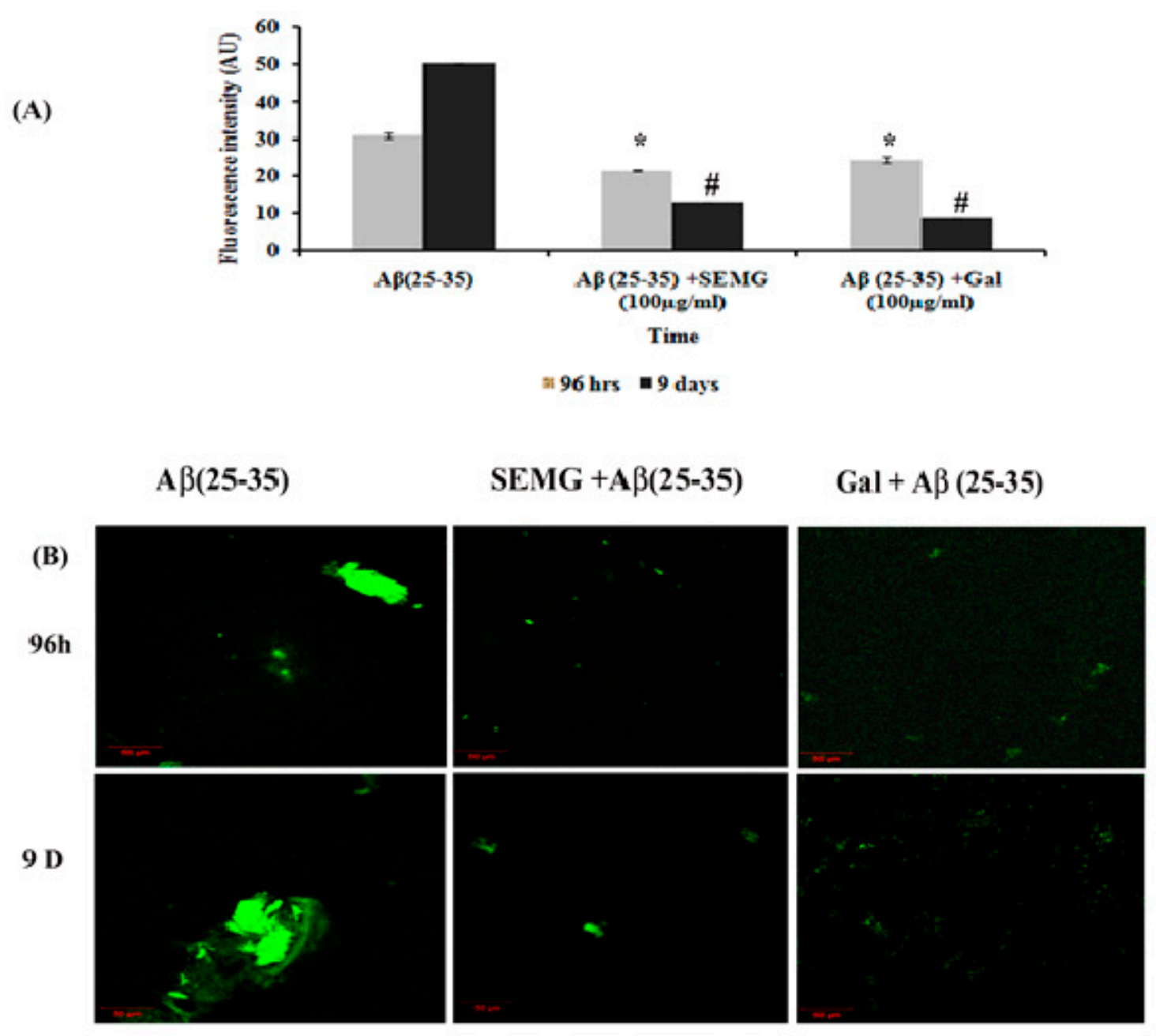

Figure 5. Effect of SEMG on the disintegration of preformed mature fibrils. (A) Th-T fluorescence assay, (B) confocal laser scanning microscopic analysis. ${ }^{*}, \# p<0.05$ represents statistically significant difference in comparison with treated groups with control and positive control group.

\section{SEMG Pretreatment Prevented A $\beta$-Induced Toxicity in Neuro2A Cell Lines}

The neuroprotective effect of SEMG against A $\beta$ (25-35)-induced toxicity was assessed by the MTT assay. Results revealed that treatment of Neuro2A with A $\beta$ (25-35) for $24 \mathrm{~h}$ reduced the viability of the cells dose-dependently, with a reduction by $49.72 \% \pm 4.27 \%$ at the highest dose of $50 \mu \mathrm{M}$, and this dose was fixed for further studies (Figure 6A). 
Pretreatment with SEMG (25-100 $\mu \mathrm{g} / \mathrm{mL})$ resulted in the reduction of A $\beta$ (25-35)-induced cytotoxicity dose-dependently, restoring the viability of the cells to $99.99 \% \pm 1.98 \%$ at $100 \mu \mathrm{g} / \mathrm{mL}$ (Figure 6A). IC $_{50}$ value of SEMG was observed to be $18.25 \pm 0.025 \mu \mathrm{g} / \mathrm{mL}$ (Figure 6B). The increase in cell viability may be due to the high antioxidant potential of SEMG which could have attenuated the oxidative stress induced by A $\beta$ (25-35) toxicity. Furthermore, the protective effect of SEMG against A $\beta$ (25-35)-induced toxicity was further substantiated by trypan blue exclusion studies (Supplementary Figure S1). Phase contrast microscopic image of $A \beta$ (25-35)-treated cells revealed the presence of classical epithelial morphology with tight cell-to-cell adhesion in vehicle control, while A $\beta$ (25-35)-treated cells showed round and shrunk cells with loss of extensions associated with reduction in cell count. In some cells, membrane blebbing with condensed nuclei were observed, illustrating characteristic features of apoptosis [41]. However, SEMG-treated cells showed morphological features similar to vehicle control, revealing the protective effect of SEMG against $A \beta$ (25-35)-induced toxicity (Figure 6C).

(A)

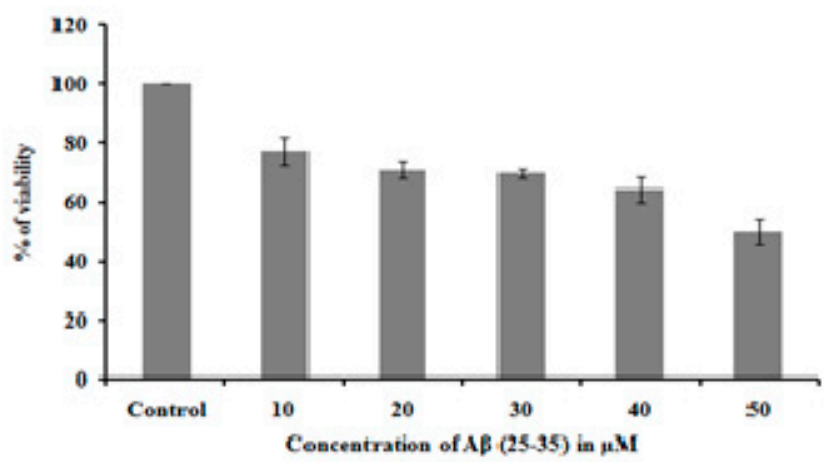

(B)

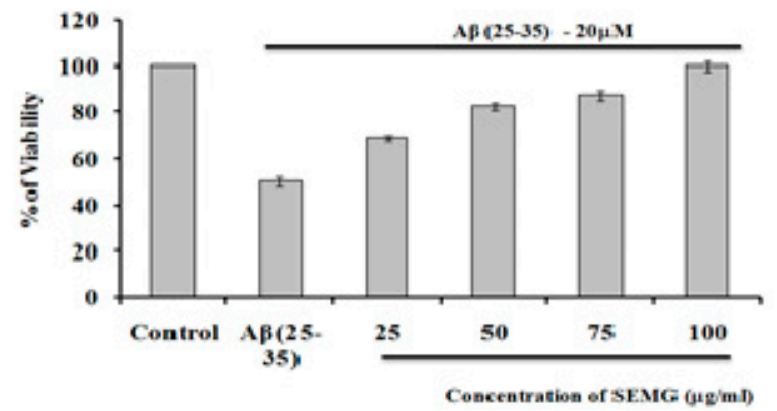

(C)
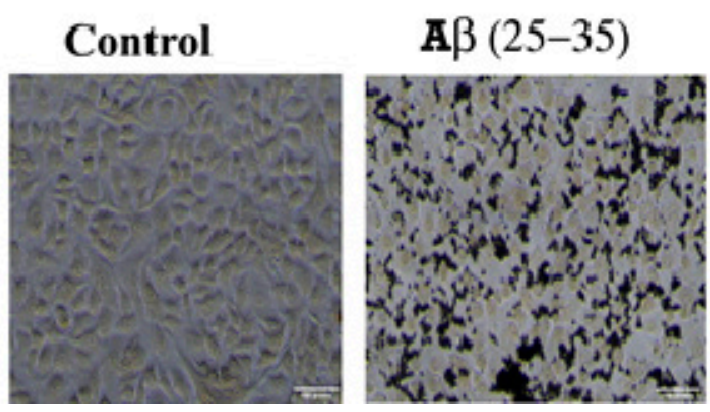

\section{SEMG}

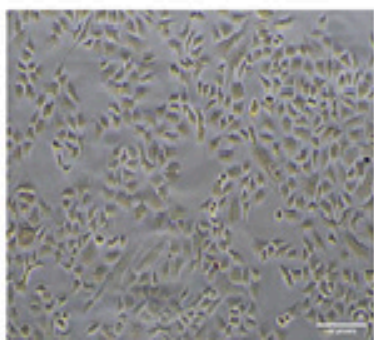

Figure 6. (A) Assessment of in vitro cytotoxic effect of Beta amyloid peptide $(\mathrm{A} \beta(25-35))(10-500 \mu \mathrm{M})$ in Neuro2A cell lines; (B) Evaluation of protective effect of SEMG against A $\beta$ (25-35) induced toxicity; (C) Phase contrast microscopic analysis to assess the morphological changes induced by A $\beta$ (25-35) toxicity with magnification $20 \times$. 
Role of SEMG in Attenuating ROS and RNS (Reactive Nitrogen Species) Levels Induced by $\mathrm{A} \beta(25-35)$ Toxicity

Multiple evidences revealed that $\mathrm{A} \beta$ peptide during oligomerization induced the release of $\mathrm{H}_{2} \mathrm{O}_{2}$ in the presence of transition metal ions $\mathrm{Fe}^{2+}$ or $\mathrm{Cu}^{2+}$, which in turn promotes Fenton chemistry enhancing the production of ROS and RNS, leading to lipid peroxidation and protein oxidation [42,43]. In the present study, the effect of SEMG was assessed by measuring intracellular ROS and RNS levels. DCFH-DA, a fluorescent probe, was used to assess the cellular ROS level. Results revealed that cells treated with A $\beta$ showed a one-fold increase in fluorescent intensity (303.66 \pm 4.92 a.u) when compared to vehicle control (196.33 \pm 4.92 a.u.), while SEMG-treated groups attenuated A $\beta$-induced ROS level, restoring it to normal (Figure 7A). Confocal microscopic images showed increased green fluorescence in $A \beta$-treated groups, while SEMG-treated groups showed reduced green fluorescence similar to vehicle control (Figure 7B).

(A)

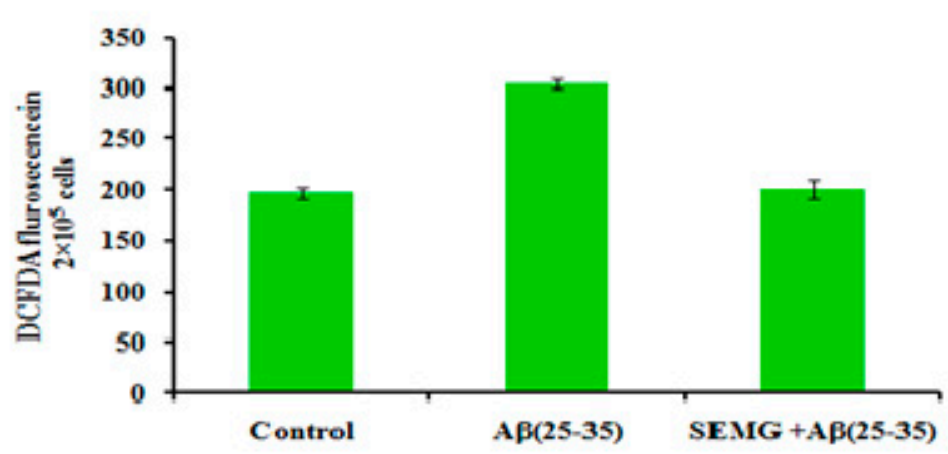

(B) Control
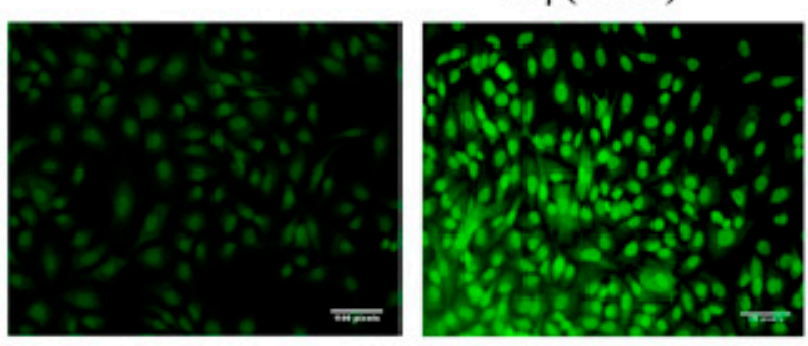

SEMG + A $\beta(25-35)$

(C)

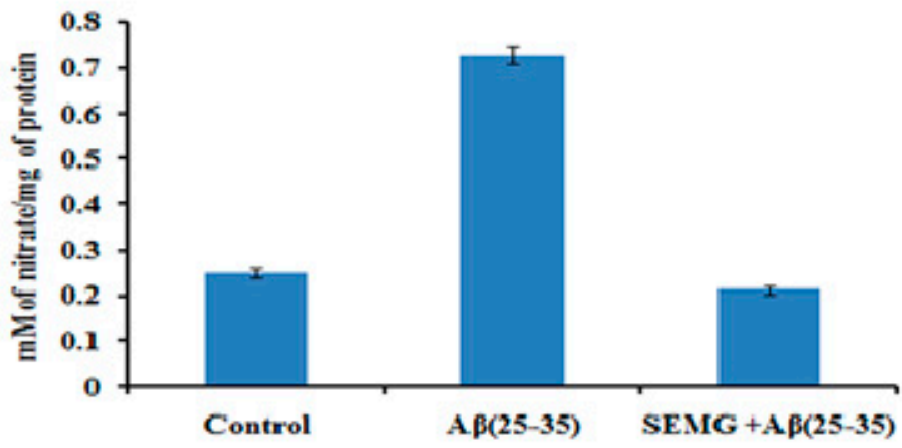

Figure 7. (A) Measurement of ROS level in cells exposed to A $\beta$ (25-35) co-treated with SEMG by spectro fluorimetric analysis; (B) Fluorescence microscopic images of Neuro2A cells illustrating intracellular ROS level with $20 \times$ magnification; (C) RNS scavenging effect of SEMG in cells treated with $A \beta(25-35)$. Data are expressed as Mean \pm SD of triplicate assays. 
A $\beta$ (25-35)-treated cells showed a significant increase in nitric oxide level $(0.729 \pm 0.018 \mathrm{mM}$ of nitrate $/ \mathrm{mg}$ of protein), while SEMG-treated groups reduced the nitric oxide level $(0.213 \pm 0.008 \mathrm{mM}$ of nitrate $/ \mathrm{mg}$ of protein) similar to vehicle control $(0.249 \pm 0.019 \mathrm{mM}$ of nitrate $/ \mathrm{mg}$ of protein), which might be due to the antioxidative potential of SEMG (Figure 7C).

Effect of SEMG on Lipid Peroxidation and Protein Oxidation Induced by A $\beta$ (25-35) Toxicity

Multiple laboratory and clinical evidences revealed the presence of elevated levels of oxidative stress markers of lipid peroxidation and protein oxidation, like 4-hydroxynonenal and protein carbonyl content, in the brain of AD patients [44,45]. To verify the free radical scavenging activity of SEMG, the degree of lipid peroxidation and protein oxidation with thiobarbituric acid reactive substances (TBARS) and protein carbonyl content (PCC) as indicators was assessed in A $\beta$-exposed cells pretreated with SEMG. In the present study, cells treated with $A \beta$ showed a five-fold increase in TBARS and a two-fold increase in PCC content (195 $\pm 4.47 \mu \mathrm{M}$ of free carbonyl content/mg of protein), while SEMG-treated cells averted lipid peroxidation (35.13 $\pm 2.86 \mu \mathrm{M}$ of TBARS/mg of protein) and protein oxidation ( $109 \pm 3.22 \mu \mathrm{M}$ of carbonyl content $/ \mathrm{mg}$ of protein), restoring its level similar to vehicle control (Figure 8A, B). The restoration of TBARS and protein carbonyl content of SEMG might be due to the antioxidant potential of MG, which quenched the ROS and RNS liberated by $\mathrm{A} \beta$-induced toxicity.

SEMG Protected Neuro2A Cells from Mitochondrial Membrane Potential (MMP) Loss Induced by $A \beta$ Toxicity

The changes in MMP induced by $\mathrm{A} \beta$ toxicity were assessed by using lipophilic fluorescent dye JC-1. Fluorescent microscopic studies revealed that vehicle control cells showed uniformly red fluorescent cells (JC-1 aggregates), indicating the presence of intact mitochondrial transmembrane, while $A \beta$-treated cells showed loss of red fluorescent cells complemented with appearance of green fluorescence cells (JC-1 monomer), revealing the fact that dye diffused into cytoplasm due to disruption of MMP-the initial step of the apoptotic pathway (Figure 8C). However, SEMG-treated cells revealed the presence of red fluorescent cells, depicting the fact that SEMG attenuated ROS-induced disruption in MMP. Quantitative analysis illustrated that cells treated with A $\beta$ (25-35) showed an eight-fold reduction in the ratio of red/green fluorescence intensity, revealing the fact that $A \beta$ triggered MMP collapse (Figure 8D), while SEMG-treated cells restored the ratio (3.08 \pm 0.51$)$ similar to vehicle control $(4.67 \pm 0.424)$, depicting the fact that SEMG attenuated ROS-induced MMP loss, thereby blocking the activation of the apoptotic pathway.

\section{SEMG Impedes Apoptosis in Neuro2A Cells Induced by A $\beta$ Toxicity}

Loss of MMP due to $A \beta$ toxicity leads to activation of the apoptotic pathway, leading to neuronal death. In the present study, the anti-apoptotic effect of SEMG against A $\beta$ induced toxicity was assessed by the $\mathrm{AO} / \mathrm{EtBr}$ dual-staining technique, widely used to identify morphological changes associated with apoptosis. Results showed the presence of uniformly stained green fluorescence cells, illustrating viable cells in vehicle control, while $A \beta$-treated cells showed the presence of orange red fluorescent cells, indicating late apoptotic stage (Figure 9B). SEMG co-treated cells showed the presence of green fluorescence cells, indicating the fact that MG attenuates $A \beta$-induced apoptosis. Quantification studies revealed the presence of increased percentage of apoptotic cells in A $\beta$ (25-35)-induced toxicity $(62.33 \% \pm 1.86 \%$ and $37.66 \% \pm 1.9 \%$ apoptotic and viable cells) when compared to vehicle control $(95 \% \pm 1.78 \%$ and $5 \% \pm 1.8 \%$ live and apoptotic cells), while SEMG-treated cells showed a reduction in apoptotic cells $(24.66 \% \pm 2.25 \%)$ and in increase in viable cell count $(75.33 \% \pm 2.3 \%$ ) (Figure $9 \mathrm{~A})$. The results illustrated that SEMG exhibited an anti-apoptotic effect. 
(A)

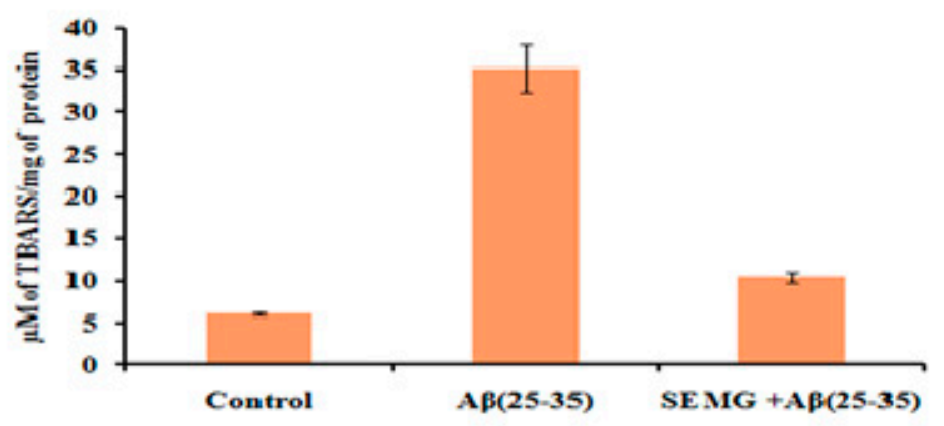

(B)

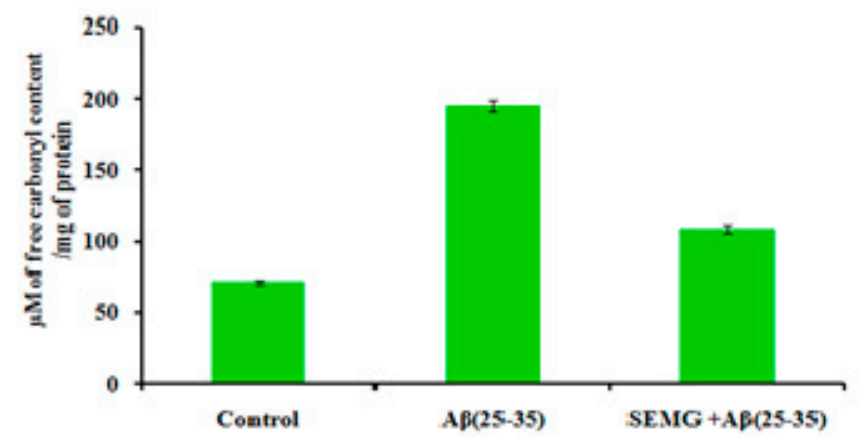

(C)

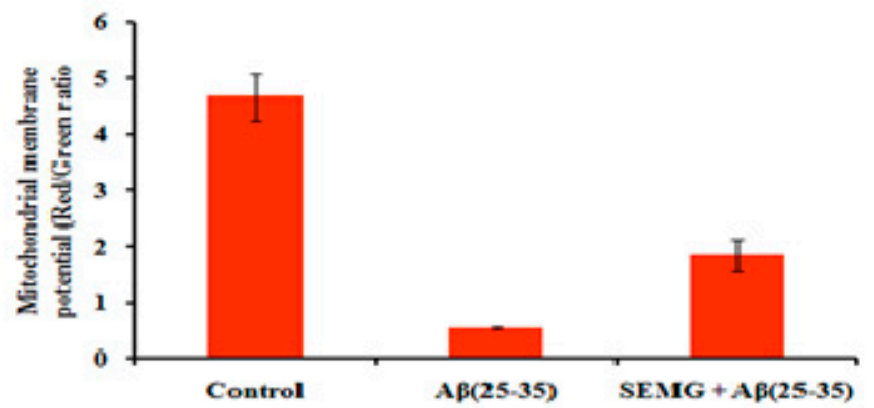

\section{(D) Control}

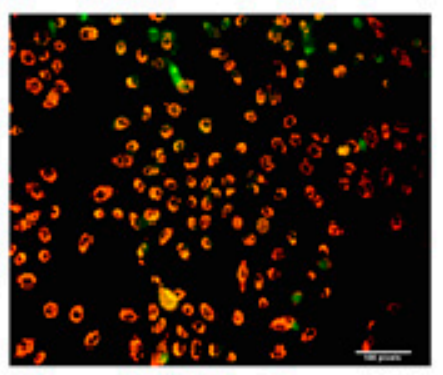

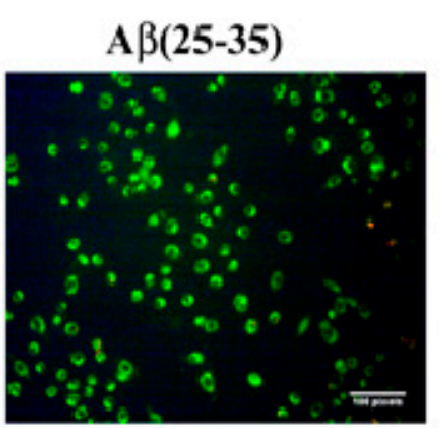

SEMG + A $\beta$ (25-35)

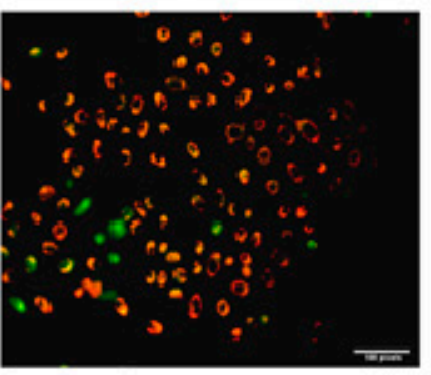

Figure 8. Effect of SEMG on A $\beta$ (25-35) induced (A) lipid peroxiation; (B) protein oxidation in Neuro2A cells; (C) Bar diagram illustrating the restoration of MMP loss in cells treated with SEMGF; (D) Fluorescent microscopic analysis representing the prevention of loss of MMP by SEMG treated groups using JC-1 staining with $20 \times$ magnification. 
(A)

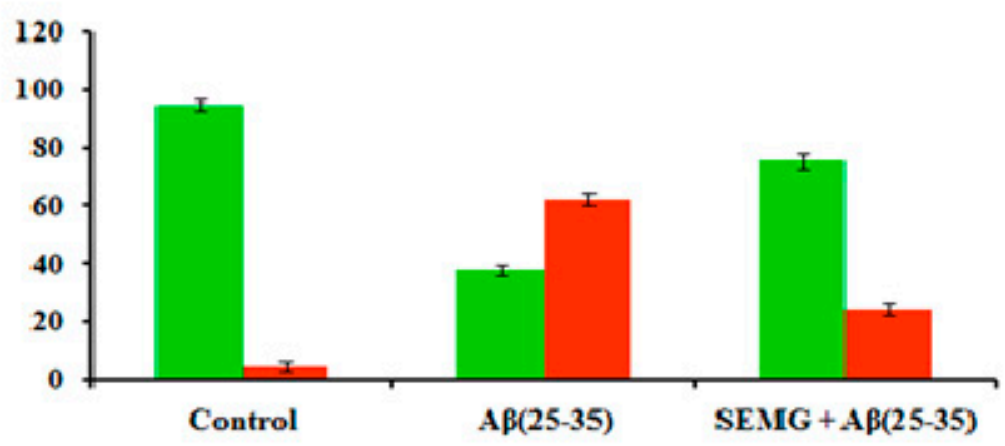

E \% of apoptosis $\quad$ = \% of survival

(B) Control

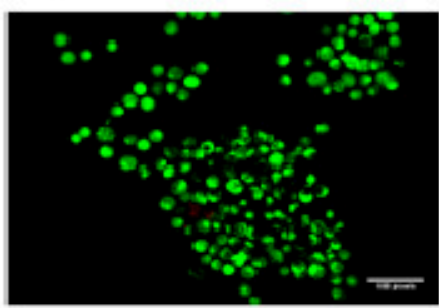

$\mathbf{A} \beta(25-35)$

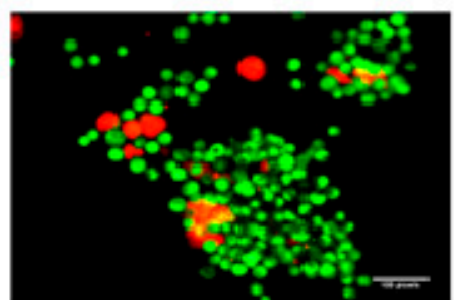

SEMG $+\mathbf{A} \beta(25-35)$

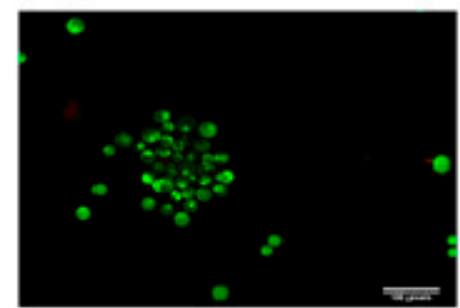

(C)

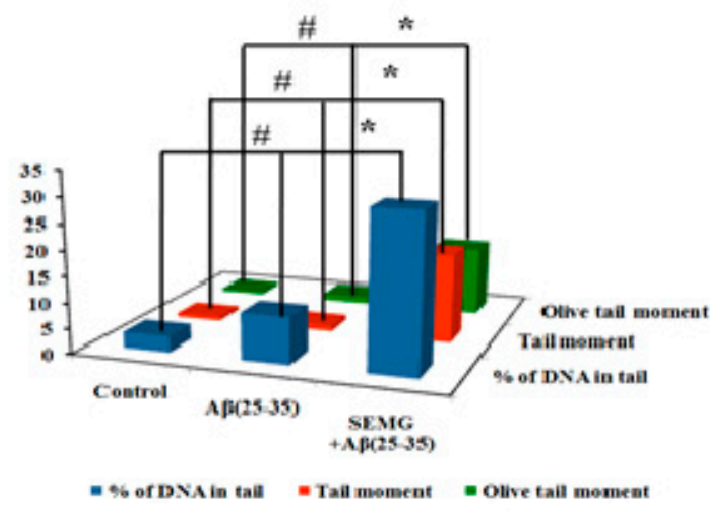

(D) Control

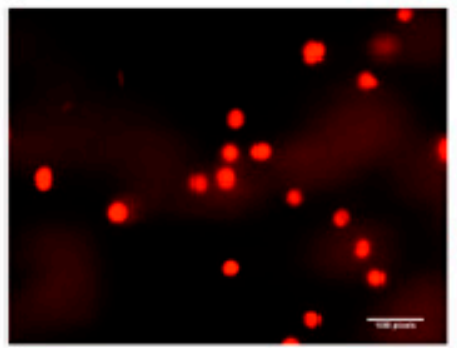

$\mathbf{A} \hat{\beta}(\mathbf{2 5 - 3 5 )}$

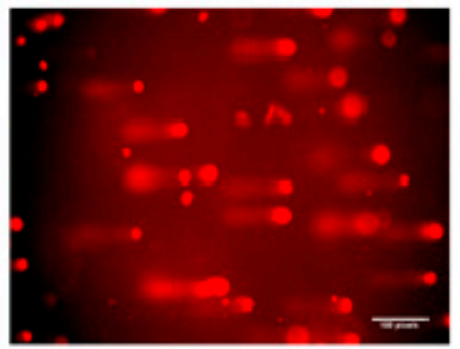

SEMG $+\mathbf{A} \beta$ (25-35)

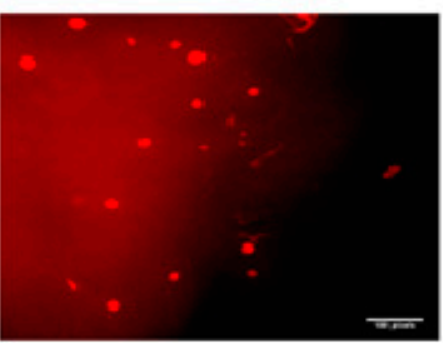

Figure 9. Assessment of antiapoptotic effect of SEMG in A $\beta$ treated Neuro2A cells by Acridine orange/Ethidium Bromide dual staining technique (A) Quantification of apoptotic population; (B) Fluorescent microscopic image revealing the presence of viable cells, apoptotic and necrotic cells * \& \# $p<0.05$ denotes the statistical significance between the control and treated groups with respect to viable and apoptotic cells; (C) Bar diagram illustrating the SEMG ability to attenuate the DNA damage in cells treated with $A \beta(25-35)$; (D) Fluorescent microscopic images illustrating the DNA damaging effect of $A \beta(25-35)$ treatment and attenuating effect of SEMG by comet assay at $20 \times$ magnification. Data are expressed as mean \pm SD of triplicate assays. Images were captured at $20 \times$ magnification respectively. 


\section{Protective Effect of SEMG Against $A \beta$-Induced Genotoxicity}

To assess the genotoxic effect of A $\beta$ (25-35) in Neuro2A cells, single-cell gel electrophoresis was carried out. Fluorescence microscopic images showed the presence of large non-fragmented intact nucleoids in vehicle control-treated cells, while $A \beta$-treated cells showed an increase in the length of DNA tail (DNA damage), which provided the appearance of comet during alkaline gel electrophoresis (Figure 9C). SEMG-treated cells showed intact cell morphology similar to vehicle control. Figure 9D illustrates the levels of DNA damage in terms of \% of tail DNA, length of the tail and tail moment. Vehicle control cells showed $97 \% \pm 0.09 \%$ head DNA with $3.09 \% \pm 0.02 \%$ tail DNA respectively, while $\mathrm{A} \beta$-treated groups showed $30.33 \% \pm 0.003 \%$ of DNA in tail, depicting the fact that $\mathrm{A} \beta$ induced apoptotic cell death (Figure 7B). SEMG-treated cells exhibited $91.09 \% \pm 0.02 \%$ of head DNA and $9.02 \% \pm 0.009 \%$ of DNA in tail, depicting that MG in SEMG attenuated ROS-mediated DNA damage induced by A $\beta$ toxicity.

\section{Conclusions}

The present study reported, for the first time, fabrication of starch-encapsulated methyl gallate by the graft polymerization technique. Fabricated SEMG showed high encapsulation efficiency and sustained release of drug MG under physiological pH 7.4. SEMG exhibited acetylcholinesterase inhibitory activity and antioxidant capacity. In addition, SEMG also attenuated aggregation of $A \beta$ peptide and disaggregated the preformed amyloid plaques, illustrating the fact that SEMG restored the anti-amyloidogenic effect of MG. SEMG exhibited neuroprotective effect by attenuating ROS-mediated mitochondrial dysfunction and DNA damage induced by A $\beta$ toxicity in Neuro2A cells. To conclude, the results of the present study revealed that starch-based nano-carriers are suitable for the delivery of the drug methyl gallate for the treatment of Alzheimer's disease and other related neurodegenerative disorders.

Supplementary Materials: The following are available online at https:/ / www.mdpi.com/1999-4 923/13/3/299/s1, Figure S1: (A) Assessment of in vitro cytotoxic effect of A $\beta$ (25-35) (10-50 M) in Neuro 2A cell lines; (B) Evaluation of protective effect of SEMG against A $\beta$ (25-35) induced toxicity by trypan blue exclusion assay.

Author Contributions: N.S. contributed to conception, methodology and original draft preparation; N.P. was involved in formal analysis and investigation of the work; B.S.S. and C.C. were involved in conception, designing, review and finalization of the manuscript. All authors have read and agreed to the published version of the manuscript.

Funding: This research was funded by University Grants Commission, New Delhi, India (UGC-Startup grant-Ref. No.F. 30-381/2017 (BSR), dated 06.07.2017), Department of Science and TechnologyPromotion of University Research and Scientific Excellence (DST-PURSE Phase II/P1464/2019, dated 12.11.2019). This project was partially supported by Chiang Mai University, Thailand.

Conflicts of Interest: The authors declare no conflict of interest.

\section{References}

1. Hoyos-Leyva, J.D.; Bello-Pérez, L.A.; Alvarez-Ramirez, J.; Garcia, H.S. Microencapsulation using starch as wall material: A review. Food Rev. Int. 2018, 34, 148-161. [CrossRef]

2. Wandrey, C.; Bartkowiak, A.; Harding, S.E. Materials for encapsulation. In Encapsulation Technologies for Active Food Ingredients and Food Processing; Springer: New York, NY, USA, 2010; pp. 31-100.

3. Janaswamy, S. Encapsulation altered starch digestion: Toward developing starch-based delivery systems. Carbohydr. Polym. 2014, 101, 600-605. [CrossRef]

4. Prince, M.; Bryce, R.; Albanese, E.; Wimo, A.; Ribeiro, W.; Ferri, C.P. The global prevalence of dementia: A systematic review and metaanalysis. Alzheimer's Dement. 2013, 9, 63-75. [CrossRef]

5. López, O.L.; DeKosky, S.T. Clinical symptoms in Alzheimer's disease. In Handbook of Clinical Neurology; 2008; Volume 89, pp. 207-216.

6. Tiwari, S.; Atluri, V.; Kaushik, A.; Yndart, A.; Nair, M. Alzheimer's disease: Pathogenesis, diagnostics, and therapeutics. Int. J. Nanomed. 2019, 14, 5541. [CrossRef] [PubMed] 
7. Weller, J.; Budson, A. Current understanding of Alzheimer's disease diagnosis and treatment. F1000 Research 2018. [CrossRef] [PubMed]

8. Tavanti, F.; Pedone, A.; Menziani, M.C. Computational Insight into the Effect of Natural Compounds on the Destabilization of Preformed Amyloid- $\beta(1-40)$ Fibrils. Molecules 2018, 23, 1320. [CrossRef]

9. Scarmeas, N.; Luchsinger, J.A.; Schupf, N.; Brickman, A.M.; Cosentino, S.; Tang, M.X.; Stern, Y. Physical activity, diet, and risk of Alzheimer disease. JAMA 2009, 302, 627-637. [CrossRef]

10. Scarmeas, N.; Stern, Y.; Mayeux, R.; Luchsinger, J.A. Mediterranean diet, Alzheimer disease, and vascular mediation. Arch. Neurol. 2006, 63, 1709-1717. [CrossRef]

11. Harilal, S.; Jose, J.; Parambi, D.G.T.; Kumar, R.; Mathew, G.E.; Uddin, M.S.; Kim, H.; Mathew, B. Advancements in nanotherapeutics for Alzheimer's disease: Current perspectives. J. Pharm. Pharmacol. 2019, 71, 1370-1383. [CrossRef]

12. Bebouta, D.; Pagola, S. Methyl gallate. Acta Crystallogr. Sect. E 2009, E65, o317-o318. Available online: https://journals.iucr.org/ e/issues/2009/02/00/rz2286/rz2286.pdf (accessed on 23 February 2021).

13. Chaudhuri, D.; Ghate, N.B.; Singh, S.S.; Mandal, N. Methyl gallate isolated from Spondias pinnata exhibits anticancer activity against human glioblastoma by induction of apoptosis and sustained extracellular signal-regulated kinase $1 / 2$ activation. Pharmacogn. Mag. 2015, 11, 269-276.

14. Rosas, E.C.; Correa, L.B.; das Graças Henriques, M. Antiinflammatory Properties of Schinus terebinthifolius and Its Use in Arthritic Conditions. In Bioactive Food as Dietary Interventions for Arthritis and Related Inflammatory Diseases; Elsevier: Amsterdam, The Netherlands, 2019; pp. 489-505.

15. Pugazhendhi, A.; Beema Shafreen, R.; Pandima Devi, K.; Suganthy, N. Assessment of antioxidant, anticholinesterase and antiamyloidogenic effect of Terminalia chebula, Terminalia arjuna and its bioactive constituent 7-Methyl gallic acid-An in vitro and in silico studies. J. Mol. Liq. 2018, 257, 69-81. [CrossRef]

16. Nallasamy, P.; Ramalingam, T.; Nooruddin, T.; Shanmuganathan, R.; Arivalagan, P.; Natarajan, S. Polyherbal drug loaded starch nanoparticles as promising drug delivery system: Antimicrobial, antibiofilm and neuroprotective studies. Process Biochem. 2020, 92, 355-364. [CrossRef]

17. Winarti, C.; Richana, N.; Mangunwidjaja, D.; Sunarti, T.C. Effect of arrowroot nano starch preparation methods on the characteristics of temulawak oleoresin microcapsules. In Proceedings of the 2 nd International Conference on Agriculture Postharvest Handling and Processing, Kuta, Bali, Indonesia, 29-31 August 2018; Institute of Physics Publishing: Bristol, UK, 2019; Volume 309.

18. Shimada, K.; Fujikawa, K.; Yahara, K.; Nakamura, T. Antioxidative Properties of Xanthan on the Autoxidation of Soybean Oil in Cyclodextrin Emulsion. J. Agric. Food Chem. 1992, 40, 945-948. [CrossRef]

19. Oyaizu, M. Studies on products of browning reaction. Jpn. J. Nutr. Diet. 1986, 44, 307-315. [CrossRef]

20. Ingkaninan, K.; De Best, C.M.; Van Der Heijden, R.; Hofte, A.J.P.; Karabatak, B.; Irth, H.; Verpoorte, R. High-performance liquid chromatography with on-line coupled UV, mass spectrometric and biochemical detection for identification of acetylcholinesterase inhibitors from natural products. J. Chromatogr. A 2000, 872, 61-73. [CrossRef]

21. Khurana, R.; Coleman, C.; Ionescu-Zanetti, C.; Carter, S.A.; Krishna, V.; Grover, R.K.; Singh, S. Mechanism of thioflavin T binding to amyloid fibrils. J. Struct. Biol. 2005, 151, 229-238. [CrossRef]

22. Mosmann, T. Rapid colorimetric assay for cellular growth and survival: Application to proliferation and cytotoxicity assays. J. Immunol. Methods 1983, 65, 55-63. [CrossRef]

23. Eruslanov, E.; Kusmartsev, S. Identification of ROS using oxidized DCFDA and flow-cytometry. Methods Mol. Biol. 2010, 594, 57-72. [PubMed]

24. Sivandzade, F.; Bhalerao, A.; Cucullo, L. Analysis of the Mitochondrial Membrane Potential Using the Cationic JC-1 Dye as a Sensitive Fluorescent Probe. Bio-Protocol 2019, 9, e3128. [CrossRef]

25. Ohkawa, H.; Ohishi, N.; Yagi, K. Assay for lipid peroxides in animal tissues by thiobarbituric acid reaction. Anal. Biochem. 1979, 95, 351-358. [CrossRef]

26. Levine, R.L.; Garland, D.; Oliver, C.N.; Amici, A.; Climent, I.; Lenz, A.G.; Stadtman, E.R. Determination of Carbonyl Content in Oxidatively Modified Proteins. Methods Enzymol. 1990, 18, 464-478.

27. Kasibhatla, S.; Amarante-Mendes, G.P.; Finucane, D.; Brunner, T.; Bossy-Wetzel, E.; Green, D.R. Acridine Orange/Ethidium Bromide (AO/EB) Staining to Detect Apoptosis. CSH Protoc. 2006, 2006, pdb.prot4493. [CrossRef] [PubMed]

28. Zhang, L.; Liu, Y.; Wang, Y. Deprotonation mechanism of methyl gallate: UV spectroscopic and computational studies. Int. J. of Mol. Sci. 2018, 19, 3111. [CrossRef]

29. Liu, C.; Ge, S.; Yang, J.; Xu, Y.; Zhao, M.; Xiong, L.; Sun, Q. Adsorption mechanism of polyphenols onto starch nanoparticles and enhanced antioxidant activity under adverse conditions. J. Funct. Foods 2016, 26, 632-644. [CrossRef]

30. Tattiyakul, J.; Naksriarporn, T.; Pradipasena, P.; Miyawaki, O. Effect of moisture on hydrothermal modification of yam Dioscorea hispida Dennst starch. Starch/Staerke 2006, 58, 170-176. [CrossRef]

31. Ul Ain, N.; Aslam, Z.; Yousuf, M.; Waseem, W.A.; Bano, S.; Anis, I.; Shah, M.R. Green synthesis of methyl gallate conjugated silver nanoparticles: A colorimetric probe for gentamicin. New J. Chem. 2019, 43, 1972-1979. [CrossRef]

32. Cazotti, J.C.; Fritz, A.T.; Garcia-Valdez, O.; Smeets, N.M.B.; Dubé, M.A.; Cunningham, M.F. Graft modification of starch nanoparticles using nitroxide-mediated polymerization and the grafting from approach. Carbohydr. Polym. 2020, $228,115384$. [CrossRef] [PubMed] 
33. Kumar, P.; Senthamilselvi, S.; Govindaraju, M. Phloroglucinol-encapsulated starch biopolymer: Preparation, antioxidant and cytotoxic effects on HepG2 liver cancer cell lines. RSC Adv. 2014, 4, 26787-26795. [CrossRef]

34. Kumari, A.; Yadav, S.K. Cellular interactions of therapeutically delivered nanoparticles. Expert Opin. Drug Deliv. 2011, 8, 141-151. [CrossRef] [PubMed]

35. Venkatesan, R.; Pichaimani, A.; Hari, K.; Balasubramanian, P.K.; Kulandaivel, J.; Premkumar, K. Doxorubicin conjugated gold nanorods: A sustained drug delivery carrier for improved anticancer therapy. J. Mater. Chem. B 2013, 1, 1010-1018. [CrossRef]

36. Fonseca-Santos, B.; Gremião, M.P.D.; Chorilli, M. Nanotechnology-based drug delivery systems for the treatment of Alzheimer's disease. Int. J. Nanomed. 2015, 10, 4981-5003. [CrossRef] [PubMed]

37. Yiannopoulou, K.G.; Papageorgiou, S.G. Current and Future Treatments in Alzheimer Disease: An Update. J. Cent. Nerv. Syst. Dis. 2020, 12, 117957352090739. [CrossRef] [PubMed]

38. Baranowska-Wójcik, E.; Szwajgier, D. Alzheimer's disease: Review of current nanotechnological therapeutic strategies. Expert Rev. Neurother. 2020, 20, 271-279. [CrossRef]

39. Sharma, K. Cholinesterase inhibitors as Alzheimer's therapeutics (Review). Mol. Med. Rep. 2019, 20, 1479-1487. [CrossRef]

40. Feng, Y.; Wang, X. Antioxidant therapies for Alzheimer's disease. Oxidative Med. Cell. Longev. 2012. [CrossRef] [PubMed]

41. Saraste, A.; Pulkki, K. Morphologic and biochemical hallmarks of apoptosis. Cardiovasc. Res. 2000, 45, 528-537. [CrossRef]

42. Butterfield, D.A.; Swomley, A.M.; Sultana, R. Amyloid $\beta$-peptide (1-42)-induced oxidative stress in Alzheimer disease: Importance in disease pathogenesis and progression. Antioxid. Redox Signal. 2013, 19, 823-835. [CrossRef] [PubMed]

43. Cheignon, C.; Tomas, M.; Bonnefont-Rousselot, D.; Faller, P.; Hureau, C.; Collin, F. Oxidative stress and the amyloid beta peptide in Alzheimer's disease. Redox Biol. 2018, 14, 450-464. [CrossRef]

44. Sultana, R.; Perluigi, M.; Butterfield, D.A. Protein oxidation and lipid peroxidation in brain of subjects with Alzheimer's disease: Insights into mechanism of neurodegeneration from redox proteomics. Antioxid. Redox Signal. 2006, 8, 2021-2037. [CrossRef] [PubMed]

45. Butterfield, D.A.; Boyd-Kimball, D. Oxidative Stress, Amyloid- $\beta$ Peptide, and Altered Key Molecular Pathways in the Pathogenesis and Progression of Alzheimer's Disease. J. Alzheimer's Dis. 2018, 62, 1345-1367. [CrossRef] [PubMed] 